\title{
Ammonia- and Methane-Oxidizing Bacteria: The Abundance, Niches and Compositional Differences for Diverse Soil Layers in Three Flooded Paddy Fields
}

\author{
Jian Zhang ${ }^{1}$, Olusanya A. Olatunji ${ }^{2}, * \mathbb{C}$, Kaiwen Pan ${ }^{3}$, Xianjun Jiang ${ }^{1}$, Yao Meng ${ }^{1}$, Jianjun $\mathrm{Li}^{4}$, \\ Jiabao Li ${ }^{3}$, Si Shen ${ }^{1}$, Dalu Guo ${ }^{1}$ and Hongyan Luo ${ }^{1, *(1)}$ \\ 1 College of Resources and Environment, SouthWest University, Beibei, Chongqing 400715, China; \\ zj20172541@email.swu.edu.cn (J.Z.); jiangxj@swu.edu.cn (X.J.); wuzan1998@email.swu.edu.cn (Y.M.); \\ sshh0802@email.swu.edu.cn (S.S.); g970118@email.swu.edu.cn (D.G.) \\ 2 College of Geographical Science, Fujian Normal University, 32 Shangsan Road, Fuzhou 350007, China \\ 3 Key Laboratory of Mountain Ecological Restoration and Bioresource Utilization \& Ecological Restoration \\ Biodiversity Conservation Key Laboratory of Sichuan Province, Chengdu Institute of Biology, Chinese \\ Academy of Sciences, Chengdu 610041, China; pankw@cib.ac.cn (K.P.); lijb@cib.ac.cn (J.L.) \\ 4 Guangdong Institute of Microbiology, Guangdong 510070, China; gong48612418@email.swu.edu.cn \\ * Correspondence: olusanya084@mails.ucas.ac.cn (O.A.O.); luo1974@swu.edu.cn (H.L.)
}

Received: 3 January 2020; Accepted: 25 January 2020; Published: 28 January 2020

\begin{abstract}
Ammonia oxidizing bacteria (AOB), Ammonia oxidizing archaea (AOA) and methane oxidizing bacteria $(\mathrm{MOB})$ play cogent roles in oxidation and nitrification processes, and hence have important ecological functions in several ecosystems. However, their distribution and compositional differences in different long-term flooded paddy fields (FPFs) management at different soil depths remains under-investigated. Using $\mathrm{QPCR}$ and phylogenetic analysis, this study investigated the abundance, niches, and compositional differences of $\mathrm{AOA}, \mathrm{AOB}$, and $\mathrm{MOB}$ along with their potential nitrification and oxidation rate in three soil layers from three FPFs (ShaPingBa (SPB), HeChuan (HC), and JiDi (JD)) in Chongqing, China. In all the FPFs, $\mathrm{CH}_{4}$ oxidation occurred mainly in the surface $(0-3 \mathrm{~cm})$ and subsurface layers $(3-5 \mathrm{~cm})$. A significant difference in potential methane oxidation and nitrification rates was observed among the three FPFs, in which SPB had the highest. The higher amoA genes are the marker for abundance of AOA compared to AOB while pmoA genes, which is the marker for $\mathrm{MOB}$ abundance and diversity, indicated their significant role in the nitrification process across the three FPFs. The phylogenetic analysis revealed that AOA were mainly composed of Nitrososphaera, Nitrosospumilus, and Nitrosotalea, while the genus Nitrosomonas accounted for the greatest proportion of AOB in the three soil layers. MOB were mainly composed of Methylocaldum and Methylocystis genera. Overall, this finding pointed to niche differences as well as suitability of the surface and subsurface soil environments for the co-occurrence of ammonia oxidation and methane oxidation in FPFs.
\end{abstract}

Keywords: AOA; AOB; MOB; q-PCR; Paddy field

\section{Introduction}

Nitrification, through which ammonia $\left(\mathrm{NH}_{3}\right)$ is converted into nitrite $\left(\mathrm{NO}_{2}{ }^{-}\right)$or nitrate $\left(\mathrm{NO}_{3}{ }^{-}\right)$, is a key process in global nitrogen $(\mathrm{N})$ cycling and is strongly linked with the release of greenhouse gases to the atmosphere, $\mathrm{NO}_{2}^{-}$leaching into ground water and $\mathrm{N}$ availability for plant use [1]. The biological oxidation of $\mathrm{NH}_{3}$ into $\mathrm{NO}_{3}{ }^{-}$is currently considered to be catalyzed by Ammonia oxidizing Bacteria (AOB) within two Proteobacteria subclasses ( $\beta$ and $\gamma$ subclasses Proteobacteria) and Ammonia oxidizing Archaea (AOA) [2]. Conversely, the oxidation of the second most abundant greenhouse 
gas, methane $\left(\mathrm{CH}_{4}\right)$, is conducted by methane-oxidizing bacteria (MOB) [3]. In paddy fields, MOB minimize the amounts of $\mathrm{CH}_{4}$ emitted into the atmosphere [4]. $\mathrm{MOB}$ are Gram-negative bacteria that utilize $\mathrm{CH}_{4}$ as the exclusive carbon and energy source. They oxidize $\mathrm{CH}_{4}$ in the aerobic environments such as the rhizosphere and the soil-water interface before it is transported into the atmosphere [5]. Studies have shown that the rate of oxidation is approximately $50 \%$ to $90 \%$ of the amount of $\mathrm{CH}_{4}$ produced [6]. Therefore, elucidating on $\mathrm{MOB}$ abundance and activity in the aerobic region, particularly in paddy fields, is critical for enhancement of the understanding of $\mathrm{CH}_{4}$ oxidation and the reduction of greenhouse gases from rice fields.

With more than half of the world's population consuming rice, several hectares of lands are continuously being converted for rice production [7]. In China, paddy field management is widely distributed and remains the main source of $\mathrm{N}_{2} \mathrm{O}$ and $\mathrm{CH}_{4}$ [3]. Because of the fundamental roles of $\mathrm{AOA}, \mathrm{AOB}$, and MOB in the $\mathrm{N}$ biogeochemical cycle, the oxidation of $\mathrm{CH}_{4}$, ecological issues and soil health, particularly in paddy field, have attracted considerable attention.

According to a previous study, nitrous oxide, which is a major greenhouse gas, is a by-product of both $\mathrm{AOB}$ and $\mathrm{AOA}$ activity [8]. In addition, $\mathrm{AOB}$ produces nitrogen monoxide, which decreases ozone levels in the stratosphere [9]. It has also been reported that AOA could possess a genetic capacity to exploit organic carbon and small organic molecules $[10,11]$. However, several environmental factors, including soil moisture, temperature, $\mathrm{NH}_{4}{ }^{+}-\mathrm{N}$ concentrations, among others, could influence the abundance and community structure of soil AOA, AOB and MOB [12]. Studies have reported archaeal $a m o A$ to be more abundant than bacterial amo $A$ in most soils $[13,14]$; however, the differences in the abundance of different types of $a m o A$ may be due to their distinct ecological niches. For example, in an agricultural soil with $\mathrm{N}$ amendments, bacterial amo $A$ are predicted to be more abundant [15], while in soil where mineralization of organic $\mathrm{N}$ influences the nitrification process, archaeal amo $A$ are expected to be more abundant. Soil type, $\mathrm{pH}$, vegetation types, and locations influence both nitrifiers and the nitrification process in soil ecosystems [16]. According to Lehtovirta-Morley et al. (2011) [17], in terrestrial ecosystems, although a specific AOA cluster is likely to occur in neutral environments, Nitrosotalea devanaterra, which is another cluster with an AOA origin, exists in acidic soils, suggesting that different AOA species respond differently to soil alkalinity or acidity. Similarly, in paddy soils, the coupling of nitrification and denitrification has been reported, with AOA exhibiting higher activity in acidic paddy soils, while AOB are primarily dominant in neutral and alkaline paddy soils, particularly in intensively $\mathrm{N}$-fertilized soil $[18,19]$. However, the distribution and compositional differences of $\mathrm{AOA}, \mathrm{AOB}$, and $\mathrm{MOB}$ in long-term nitrogen saturated flooded paddy fields (FPFs) management at different soil depths remains rarely examined.

The intensive application of $\mathrm{N}$ fertilizers has increased in recent decades, particularly in paddy fields, which has aggravated soil acidification and accelerated the rate at which most paddy fields become acidic [1]. Generally, $\mathrm{N}$ fertilizer is critical for increasing grain yield in paddy fields. However, intensive $\mathrm{N}$ fertilizer application could alter the abundance and composition of AOB in the soil [20]. For example, Shen et al. (2011) [21] observed long-term N stocking considerably influenced the abundance and composition of AOB but not AOA in a semi-arid grassland. In addition, as soil becomes flooded in the course of rice growth, oxygen $\left(\mathrm{O}_{2}\right)$ is depleted at a more rapid rate due to an interface a few millimeters beneath the soil-water [5], suggesting that the abundance of AOA and AOB, which are widespread in paddy fields, varies across soil layers. However, it is unclear how factors associated with soil depth influence AOA, AOB and MOB distribution in FPFs.

Therefore, investigating the community responses of $\mathrm{AOA}, \mathrm{AOB}$ and $\mathrm{MOB}$ in different soil layers could enhance our understating of the soil $\mathrm{N}$ cycle. In this study, soil samples were collected from three soil layers from three FPFs in Chongqing, China. The aim was to investigate the key microbial mechanisms of $\mathrm{NH}_{3}$ and $\mathrm{CH}_{4}$ oxidation in the FPFs and evaluate changes in AOA, AOB and MOB abundance and composition along the paddy field soil profiles. The study aimed to also evaluate the contributions of $\mathrm{AOA}, \mathrm{AOB}$ and $\mathrm{MOB}$ in different soil layers nitrification and oxidation processes. 
We applied qPCR techniques to identify $\mathrm{AOA}, \mathrm{AOB}$ and $\mathrm{MOB}$ and compared their abundance and occurrence among three FPFs.

\section{Materials and Methods}

\subsection{Soil Sampling and Site Characteristics}

The soil samples used in the present study were selected from three different soil layers, including the surface $(0-3 \mathrm{~cm})$, the subsurface $(3-5 \mathrm{~cm})$ and the bottom $(5-20 \mathrm{~cm})$ layers at three FPFs following crop harvest. The three experimental fields are at the Purple Soil Ecology Experimental Station of Southwest University (JD) $\left(30^{\circ} 26^{\prime} \mathrm{N}, 106^{\circ} 26^{\prime} \mathrm{E}\right)$, Hechuan (HC) $\left(36^{\circ} 1^{\prime} 12^{\prime \prime} \mathrm{N}, 118^{\circ} 59^{\prime} 31.2^{\prime \prime} \mathrm{E}\right)$, and Shapingba (SPB) $\left(29^{\circ} 43^{\prime} 39^{\prime \prime} \mathrm{N}, 106^{\circ} 19^{\prime} 57^{\prime \prime} \mathrm{E}\right)$, Chongqing, China. The average annual rainfall in the FPFs were $1105.4 \mathrm{~mm}, 1100-1300 \mathrm{~mm}$ and $1100 \mathrm{~mm}$ in JD, HC and SPB, respectively, and the average temperatures were $18.3^{\circ} \mathrm{C}, 18.1{ }^{\circ} \mathrm{C}$ and $18.2^{\circ} \mathrm{C}$, respectively. The management practices in the three FPFs included conventional fertilization treatments. At the JD sites, the application of $190 \mathrm{~kg} \mathrm{hm}^{-2}$ human and animal feces or urine containing urea, $500 \mathrm{~kg} \mathrm{hm}^{-2}$ calcium superphosphate, $75 \mathrm{~kg} \mathrm{hm}^{-2}$ potassium chloride, $80 \mathrm{~kg} \mathrm{hm}^{-2}$ urea topdressing of rice at the tillering stage and $75 \mathrm{~kg} \mathrm{hm}^{-2}$ potassium chloride were common practices. At the HC and SPB sites, ammonium sulfate combined with human waste was applied as a fertilizer.

In October 2016, three replicate soil samples were randomly collected at three layers in each of the paddy fields using a ZYA-QY Earth drill soil sampler $(70 \mathrm{~mm} \times 300 \mathrm{~mm}$, Hangzhou Billion McNair Tech., Zhejiang, China). The soils were homogenized by using manually mixing and removing visible plant debris, rocks and soil micro-fauna, and were then stored at $4{ }^{\circ} \mathrm{C}$. Soil samples for molecular analysis were stored at $-20^{\circ} \mathrm{C}$. Other soil samples were air-dried and used for the determination of basic physical and chemical properties.

\subsection{Determination of Soil Properties}

Soil $\mathrm{pH}$ was measured in a 1:2.5 (soil:water) suspension using a pH meter (320-S, Mettler-Toledo Instruments Co., Ltd., Shanghai, China). Soil organic matter (SOM) concentration was measured using the dichromate oxidation method [22]. Total nitrogen (TN) was measured using the kjeldahl method [23] and bulk density using the ring knife method. Redox potential was calculated using the depolarization method (FJA-4 redox depolarization automatic analyzer) [24]. The results for the soil chemical property tests are presented in Table 1. 
Table 1. Soil properties at the experimental sites.

\begin{tabular}{|c|c|c|c|c|c|c|c|c|c|}
\hline & \multicolumn{3}{|c|}{ Bei Bei (JD) } & \multicolumn{3}{|c|}{ He Chuan (HC) } & \multicolumn{3}{|c|}{ Sha Pingba (SPB) } \\
\hline & $0-3 \mathrm{~cm}$ & $3-5 \mathrm{~cm}$ & $5-20 \mathrm{~cm}$ & $0-3 \mathrm{~cm}$ & $3-5 \mathrm{~cm}$ & $5-20 \mathrm{~cm}$ & $0-3 \mathrm{~cm}$ & $3-5 \mathrm{~cm}$ & $5-20 \mathrm{~cm}$ \\
\hline Average rainfall (mm) & & 1105.4 & & & $1100-1300$ & & & 1100 & \\
\hline Average temperature $\left({ }^{\circ} \mathrm{C}\right)$ & & 18.3 & & & 18.1 & & & 18.2 & \\
\hline Average sunshine (h) & & 1276.7 & & & 1300 & & & 1150 & \\
\hline Frostless period (d) & & 334 & & & 331 & & & 325 & \\
\hline $\mathrm{pH}$ & 6.6 & 6.8 & 6.5 & 6.7 & 6.6 & 6.8 & 6.7 & 6.8 & 6.6 \\
\hline Eh $(\mathrm{mV})$ & $361^{b}$ & $296^{d}$ & $252^{\mathrm{f}}$ & $375^{\mathrm{a}}$ & $301^{d}$ & $288^{\mathrm{e}}$ & $344^{c}$ & $296^{d}$ & $254^{\mathrm{f}}$ \\
\hline Bulk density $\left(\mathrm{g} / \mathrm{cm}^{3}\right)$ & $1.44 \pm 0.02^{b}$ & $1.46 \pm 0.01^{b}$ & $1.49 \pm 0.01^{\mathrm{a}}$ & $1.12 \pm 0.01^{\mathrm{d}}$ & $1.13 \pm 0.02^{\mathrm{d}}$ & $1.33 \pm 0.01^{\mathrm{c}}$ & $1.31 \pm 0.03^{c}$ & $1.33 \pm 0.01^{\mathrm{c}}$ & $1.43 \pm 0.02^{b}$ \\
\hline Organic matter $(\mathrm{g} / \mathrm{kg})$ & $23.8 \pm 0.2^{d}$ & $25.0 \pm 0.3^{b}$ & $22.9 \pm 0.1^{\mathrm{e}}$ & $18.0 \pm 0.1^{\mathrm{h}}$ & $19.5 \pm 0.2^{\mathrm{f}}$ & $18.5 \pm 0.1 \mathrm{~g}$ & $25.1 \pm 0.1^{b}$ & $25.7 \pm 0.2^{\mathrm{a}}$ & $24.3 \pm 0.1^{\mathrm{c}}$ \\
\hline Total N (g/kg) & $1.31 \pm 0.02^{c}$ & $1.43 \pm 0.03^{b}$ & $1.34 \pm 0.01^{\mathrm{c}}$ & $1.17 \pm 0.01^{\mathrm{e}}$ & $1.23 \pm 0.01^{\mathrm{d}}$ & $1.11 \pm 0.02^{\mathrm{f}}$ & $1.44 \pm 0.02^{b}$ & $1.49 \pm 0.01^{\mathrm{a}}$ & $1.46 \pm 0.01^{b}$ \\
\hline
\end{tabular}

Notes: $0-3 \mathrm{~cm}$ : surface layer, $3-5 \mathrm{~cm}$ : subsurface layer, $5-20 \mathrm{~cm}$ : bottom layer. Different lower-case letters (a-f) indicate significant differences $p<0.05$. The differences at a 0.05 significance level were separately checked among soil samples. 


\subsection{Potential Nitrification Rates (PNRs) and Methane Oxidation Potentials (MOP)}

Potential nitrification rates (PNRs) were tested using the Chlorate (sodium chlorate) inhibition method [13]. Dry soil samples (5 g) were added into a $50 \mathrm{~mL}$ centrifuge tube that contained $20 \mathrm{~mL}$ of 1 $\mathrm{mM}\left(\mathrm{NH}_{4}\right)_{2} \mathrm{SO}_{4}$ and $1 \mathrm{~mL}$ of sodium chlorate solution. The tube was maintained at $25^{\circ} \mathrm{C}$ for $24 \mathrm{~h}$ in the dark and later retrieved for further analysis. The oxidation rate was calculated as follows:

$$
\frac{(S-C) \cdot 2,510,000}{5 \cdot 5 \cdot \% d m}=n\left(\mathrm{Ng}^{-1} \cdot d m \cdot 5 h^{-1}\right) .
$$

\section{S-Soil sample value (mg N); C—Control (mg N)}

The determination of soil $\mathrm{CH}_{4}$ oxidation potential was carried out according to Lü et al. (2005) [25] with some modifications. Briefly, the $\mathrm{CH}_{4}$ gas initially added to the pre-culture samples was released following the opening of the culture flask. As $1 \% \mathrm{CH}_{4}$ gas was added to the samples, $1 \%$ difluoromethane was also added to the control treatment as a $\mathrm{CH}_{4}$ oxidation inhibitor. The culture suspensions were carefully shaken after sealing the pinhole. Each treatment had three replicates and was incubated at $25^{\circ} \mathrm{C}$ in the dark. Sampling and soil $\mathrm{CH}_{4}$ oxidation potential determination were carried out on the first, fourth, seventh and tenth days after the beginning of the culture. The $\mathrm{CH}_{4}$ oxidation rate was calculated based on the slope when the concentration of $\mathrm{CH}_{4}$ in the bottle decreased linearly.

The ratio of the difference of the $\mathrm{CH}_{4}$ concentration to the sampling time interval measured based on two consecutive samples during the culture period represented the $\mathrm{CH}_{4}$ oxidation rate during the period, and the oxidation rate was calculated as follows:

$$
Q=\frac{d_{c}}{d_{t}} \times \frac{V}{W} \times \frac{M W}{M V}
$$

where: $Q$ : the oxidation rate of $\mathrm{CH}_{4}\left(\mu \mathrm{g} \mathrm{g}^{-1} \mathrm{~h}^{-1}\right) ; d c / d t$ : change of $\mathrm{CH}_{4}$ concentration per unit time $\left(\mathrm{ppm} \mathrm{mol}{ }^{-1} \mathrm{~h}^{-1}\right) ; V$ : the volume of gas in the culture flask (L); $W$ : the dry soil weight $(\mathrm{g}) ; M W$ : the molecular weight $(\mathrm{g})$ of $\mathrm{CH}_{4} ; M V$ : the volume ( $\left.\mathrm{L}\right)$ of $1 \mathrm{~mol}$ of gas in a standard state.

\subsection{Molecular Analyses}

A FastDNA SPin Kit for Soil (MP Biomedicals, LLC, United States)was used to extract soil DNA. Amplification of the qPCR products for AOA, AOB and MOB was conducted on a CFX-96 Optical Real-Time PCR System (Bio-Rad Inc. Hercules, CA, US). The primer pairs amoA-1F/amoA-2R [26], Arch-amoAF/Arch-amoAR [27], and A189f/682r [28], A189f/mb661 [29] (Table 2) were adopted for the quantitative PCR (q-PCR) assays of AOA, AOB and MOB abundance, respectively. The total volume of the PCR reaction system was $20 \mu \mathrm{L}$, which was $10 \mu \mathrm{L}$ of SYBR@ Premix EX TaqTM (TaKaRa), $0.3 \mu \mathrm{L}$ of the upstream and downstream primers $\left(20 \mathrm{pmol} \mu \mathrm{L}^{-1}\right), 1.0 \mu \mathrm{L}$ of the sample and $8.4 \mu \mathrm{L}$ of sterilized double distilled water $\left(\mathrm{ddH}_{2} \mathrm{O}\right)$. The reaction conditions are listed in Table 3. The standard curve for quantitative PCR was used to clone an $\mathrm{AOA}$ and $\mathrm{AOB}$ amoA or an $\mathrm{MOB}$ pmoA functional gene into a vector plasmid (from Shanghai Meiji Sequencing Co., Ltd.).

\begin{tabular}{|c|c|c|c|}
\hline Target & Primer Sets & Primer Sequences $\left(5^{\prime}-3^{\prime}\right)$ & References \\
\hline \multirow{2}{*}{$\mathrm{AOB}$ amoA } & amoA-1F & GGGGTTTCTACTGGTGGT & \multirow{2}{*}{ Rotthauwe(1997) } \\
\hline & amoA-2R & CCCCTCKGSAAAGCCTTCTTC & \\
\hline \multirow{6}{*}{$\begin{array}{l}\text { AOA amoA } \\
\text { MOB pmoA }\end{array}$} & Arch-amoAF & STAATGGTCTGGCTTAGACG & \multirow{6}{*}{$\begin{array}{c}\text { Beman (2006) } \\
\text { Liebner (2009) } \\
\text { Zhou (2008) }\end{array}$} \\
\hline & Arch-amoAR & GCGGCCATCCATCTGTATGT & \\
\hline & A189gc & GGNGACTGGGACTTCTGG & \\
\hline & $682 \mathrm{r}$ & GAASGCNGAGAAGAASGC & \\
\hline & $\mathrm{A} 189 \mathrm{gc}$ & GGNGACTGGGACTTCTGG & \\
\hline & mb661 & CCGGMGCAACGTCYTTACC & \\
\hline
\end{tabular}

Table 2. Specific primers for functional genes used in the present study. 
Table 3. PCR reaction conditions for microorganisms in the present study.

\begin{tabular}{|c|c|c|}
\hline Target & $\begin{array}{c}\text { General PCR Reaction } \\
\text { Conditions }\end{array}$ & $\begin{array}{c}\text { Quantitative PCR Reaction } \\
\text { Conditions }\end{array}$ \\
\hline AOB amoA & $\begin{array}{c}94{ }^{\circ} \mathrm{C} 5 \mathrm{~min} ; 32 \times\left(94{ }^{\circ} \mathrm{C} 45 \mathrm{~s}, 55^{\circ} \mathrm{C}\right. \\
\left.45 \mathrm{~s}, 72{ }^{\circ} \mathrm{C}, 1 \mathrm{~min}\right) ; 72{ }^{\circ} \mathrm{C}, 10 \mathrm{~min}, \\
\text { step at } 4{ }^{\circ} \mathrm{C} .\end{array}$ & $\begin{array}{c}95{ }^{\circ} \mathrm{C}, 5.0 \mathrm{~min} ; 35 \times\left(95^{\circ} \mathrm{C}, 30 \mathrm{~s} ; 56\right. \\
\left.{ }^{\circ} \mathrm{C}, 45 \mathrm{~s} ; 72{ }^{\circ} \mathrm{C}, 1 \mathrm{~min},\right) ; \text { Melt curve } \\
65.0{ }^{\circ} \mathrm{C} \text { to } 95.0{ }^{\circ} \mathrm{C} \text {, increment } 0.5 \\
{ }^{\circ} \mathrm{C}, 0: 05+\text { plate read. }\end{array}$ \\
\hline $\begin{array}{l}\text { AOA amoA } \\
\text { MOB pmoA }\end{array}$ & 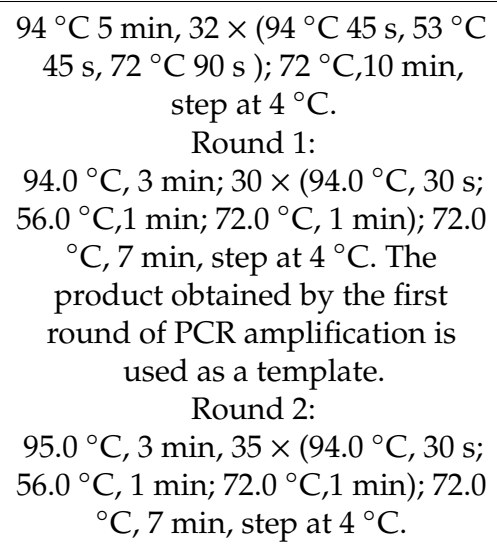 & $\begin{array}{c}95.0^{\circ} \mathrm{C}, 90 \mathrm{~s} ; 40 \times\left(95.0{ }^{\circ} \mathrm{C}, 10 \mathrm{~s} ;\right. \\
55.0^{\circ} \mathrm{C}, 30 \mathrm{~s} ; 72.0{ }^{\circ} \mathrm{C}, 30 \mathrm{~s} ; 80.0{ }^{\circ} \mathrm{C} \\
5 \mathrm{~s} \text { with plate read; Melt curve } 65.0 \\
{ }^{\circ} \mathrm{C} \text { to } 95.0{ }^{\circ} \mathrm{C} \text {, increment } 0.5^{\circ} \mathrm{C} \\
0: 05 \text { + plate read. }\end{array}$ \\
\hline
\end{tabular}

\subsection{Cloning, Sequencing, and Phylogenetic Analysis}

The target gene and Escherichia coli were recombined in vitro and then introduced into competent cells for expression and amplification. The positive clones were sent to Shanghai Meiji Company for further sequencing using a pEASY-T3 Cloning Kit (TransGen Biotech, Beijing, China). The result obtained for the cloned sequences was subjected to sequence quality control using Chromas (Technelysium, Helensvale, Queensland, Australia), and the vector sequences were deleted from the text to obtain the target gene sequences. A Blast comparison was conducted by searching the National Center for Biotechnology Information (NCBI) Gen Bank database to obtain highly similar homologous gene sequences. MEGA v4.0 [30] was used for the analysis and the sequences of all gene clones were classified based on Operating Taxonomic Units (OTUs). The neighbor joining method was used to establish phylogenetic trees to determine the phylogenetic status of sequencing clones based on their positions and genetic distances in phylogenetic trees.

\section{Statistical Analysis}

Statistical analyses were conducted using IBM SPSS Statistics 19.0 (IBM, Armonk, NY, US). Nitrification potential and microbial abundance were visualized using Origin 8.6 (OriginLab Corp., Northampton. MA, US). Gene sequencing was performed using Chromas, NCBI-Blast (https://www. ncbi.nlm.nih.gov/) and Mega v4.0 analysis and mapping.

\section{Results}

\subsection{Potential Nitrification Rates}

Potential nitrification rates were different among the FPFs and among the different soil layers. The nitrification activities ranged from $0.0150 \mu \mathrm{g} \mathrm{N} \mathrm{g}-1 \mathrm{~h}^{-1}$ in HC soil to $0.1680 \mu \mathrm{g} \mathrm{N} \mathrm{g}^{-1} \mathrm{~h}^{-1}$ in SPB soil (Figure 1). In all the FPFs, nitrification activity was significantly higher in the subsurface layers (3-5 $\mathrm{cm})$, although at different rates. Compared to the surface soil layer $(0-3 \mathrm{~cm})$, the potential nitrification rate in HC soil was significantly lower in the bottom layer $(5-20 \mathrm{~cm})$, although it was higher in SPB and JD soil (Figure 1). 


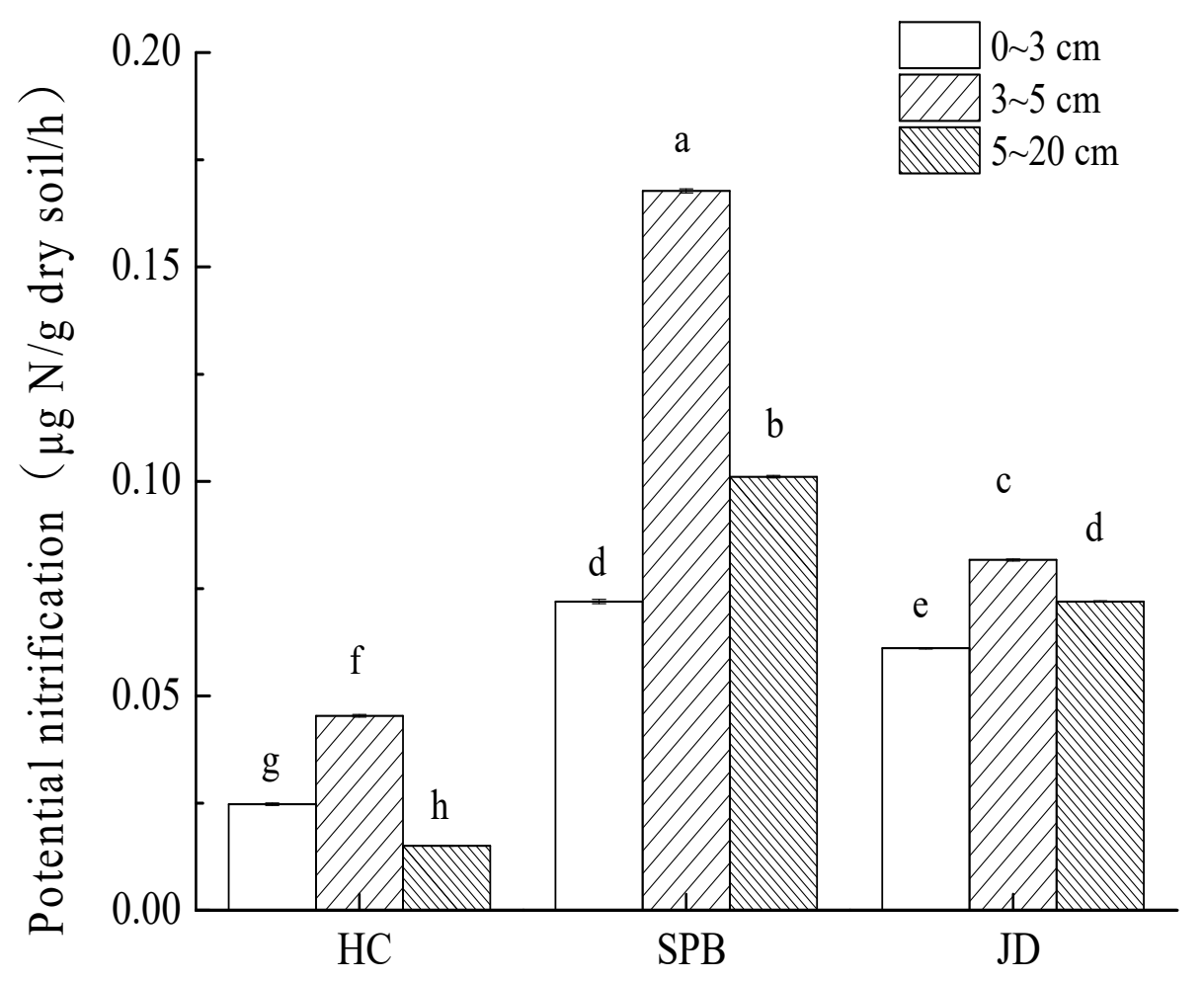

Figure 1. Nitrification activity in different soil layers in all the flooded paddy fields. Values are the averages of triplicate samples. Vertical bars indicate standard deviations. Different letters above the columns indicate significant differences $p<0.05$.

\section{2. $\mathrm{CH}_{4}$ Oxidation Potentials}

The $\mathrm{CH}_{4}$ oxidation rates in different soil layers of the three FPFs are illustrated in Figure 2. In all the FPFs, the $\mathrm{CH}_{4}$ oxidation rates were rapid initially and then decreased with an increase in incubation time (Figure 2). The average $\mathrm{CH}_{4}$ oxidation capacity of SPB soil was the highest and that of $\mathrm{HC}$ soil was the lowest, irrespective of the number of soil layers (Figure 2). The net $\mathrm{CH}_{4}$ oxidation rates in SPB soil were $0.46 \pm 0.40,0.63 \pm 0.46$ and $0.43 \pm 0.26 \mu \mathrm{g} \mathrm{CH}_{4} \mathrm{~g}^{-1} \mathrm{~h}^{-1}$ at $0-3 \mathrm{~cm}, 3-5 \mathrm{~cm}$ and $5-20 \mathrm{~cm}$, respectively. In addition, the net $\mathrm{CH}_{4}$ oxidation rates in $\mathrm{HC}$ soil were $0.43 \pm 0.33 \mu \mathrm{g} \mathrm{CH}_{4} \mathrm{~g}^{-1} \mathrm{~h}^{-1}, 0.26$ $\pm 0.15 \mu \mathrm{g} \mathrm{CH}_{4} \mathrm{~g}^{-1} \mathrm{~h}^{-1}$ and $0.22 \pm 0.19 \mu \mathrm{g} \mathrm{CH}_{4} \mathrm{~g}^{-1} \mathrm{~h}^{-1}$ at $0-3 \mathrm{~cm}, 3-5 \mathrm{~cm}$ and $5-20 \mathrm{~cm}$, respectively. The net $\mathrm{CH}_{4}$ oxidation rates in JD soil were $0.022 \pm 0.018,0.020 \pm 0.79$ and $0.91 \pm 0.93 \mu \mathrm{g} \mathrm{CH}_{4} \mathrm{~g}^{-1} \mathrm{~h}^{-1}$ at $0-3 \mathrm{~cm}, 3-5 \mathrm{~cm}$ and $5-20 \mathrm{~cm}$.

\section{3. $A O A, A O B$, and $M O B$ Abundance}

The results of the q-PCR analysis of $a m o A$ and $p m o A$ were used to determine the AOA, AOB and MOB abundance in the SPB, HC and JD soils. AOA abundance ranged from 5.28 to $1.09 \times 10^{7} / \mathrm{g}$ dry soil, 5.36 to $1.59 \times 10^{7} / \mathrm{g}$ dry soil and 3.64 to $1.10 \times 10^{7} / \mathrm{g}$ dry soil archaeal amoA gene copies in the SPB, $\mathrm{HC}$ and JD soils, respectively (Figure 3a). The highest AOA amoA abundance was observed in the bottom $(5-20 \mathrm{~cm})$ layer of the SPB and JD soils. AOB abundance ranged from 3.81 to $7.50 \times 10^{6} / \mathrm{g}$ dry soil, 1.10 to $4.27 \times 10^{6} / \mathrm{g}$ dry soil, and 1.43 to $3.14 \times 10^{6} / \mathrm{g}$ dry soil bacterial $a m o A$ gene in the SPB, HC and JD soil samples, respectively (Figure $3 b)$. The AOB amoA gene copies in the subsurface $(3-5 \mathrm{~cm})$ layer of the SPB, HC and JD soils were significantly higher than in the bottom $(5-20 \mathrm{~cm})$ layer. MOB abundance ranged from 2.56 to $1.05 \times 10^{6} / \mathrm{g}$ dry soil, 7.46 to $1.02 \times 10^{6} / \mathrm{g}$ dry soil, and 2.92 to $1.04 \times$ $10^{6} / \mathrm{g}$ dry soil pmoA gene copies in the SPB, HC and JD soils, respectively (Figure 3c). The MOB pmoA gene copies at the SPB site decreased with an increase in soil layer depth; however, no consistent trend in MOB pmoA abundance was observed in the HC and JD sites among the soil layers. The AOA/AOB 
ratio at $0-3 \mathrm{~cm}$ and $5-20 \mathrm{~cm}$ was greater than 10 across the three sites (Table 4 ) while the AOB/MOB ratio in all the three sites and at the different layers was much lower than 10.
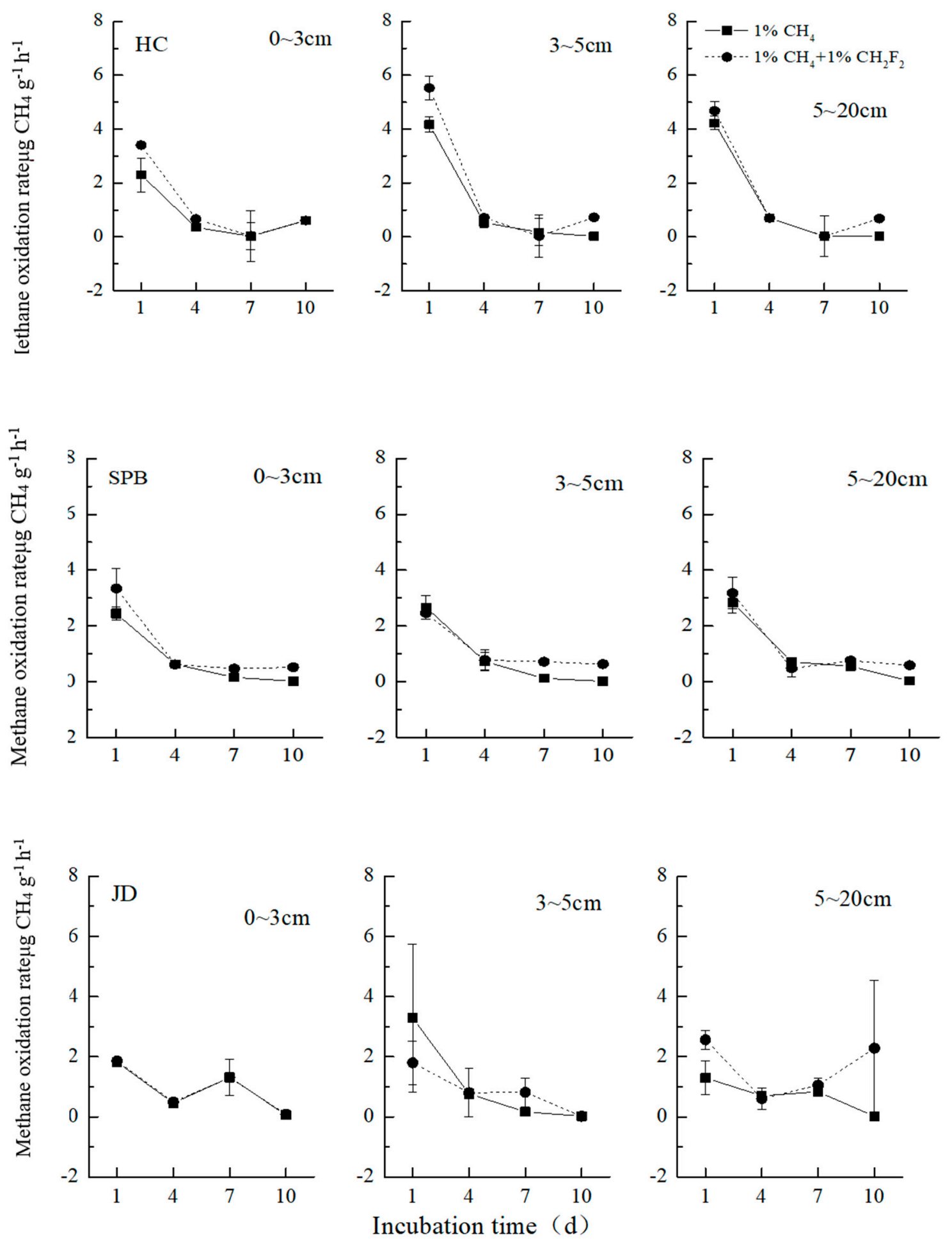

Figure 2. Methane oxidation rate in different soil layers in all the flooded paddy fields. Values are the averages of triplicate samples. Vertical bars indicate standard deviations. 


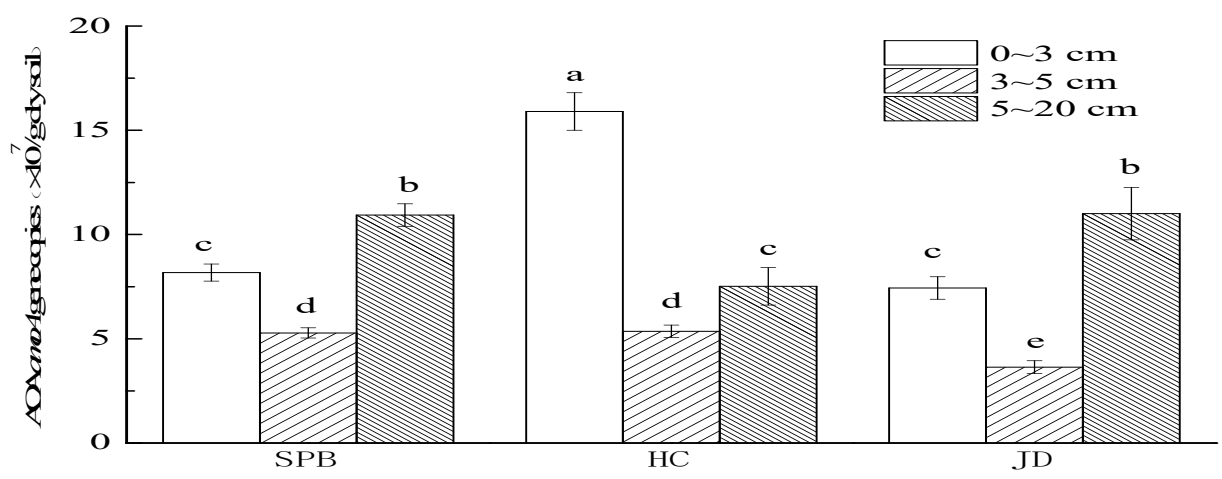

(a)

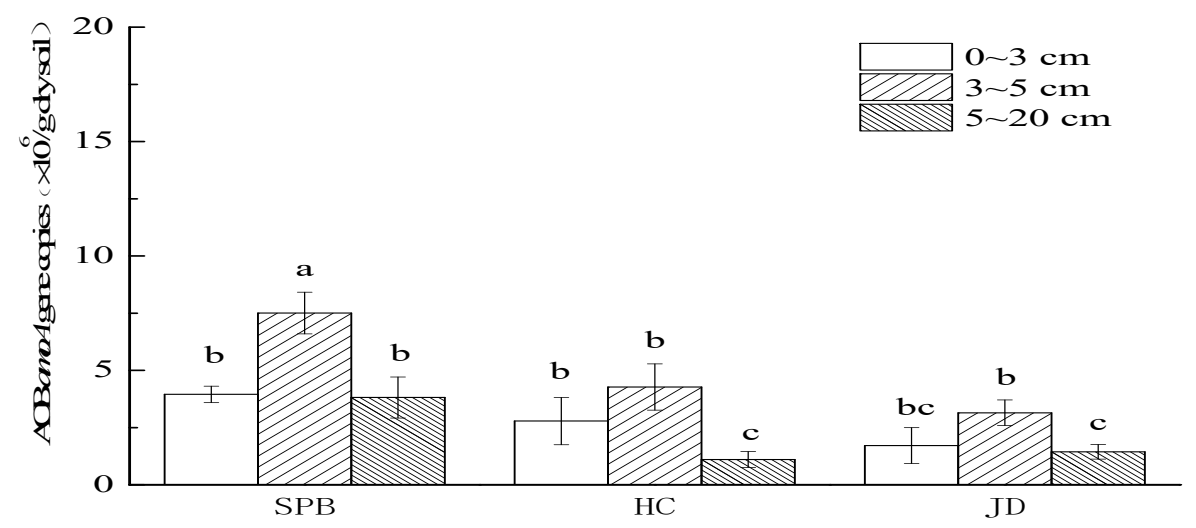

(b)

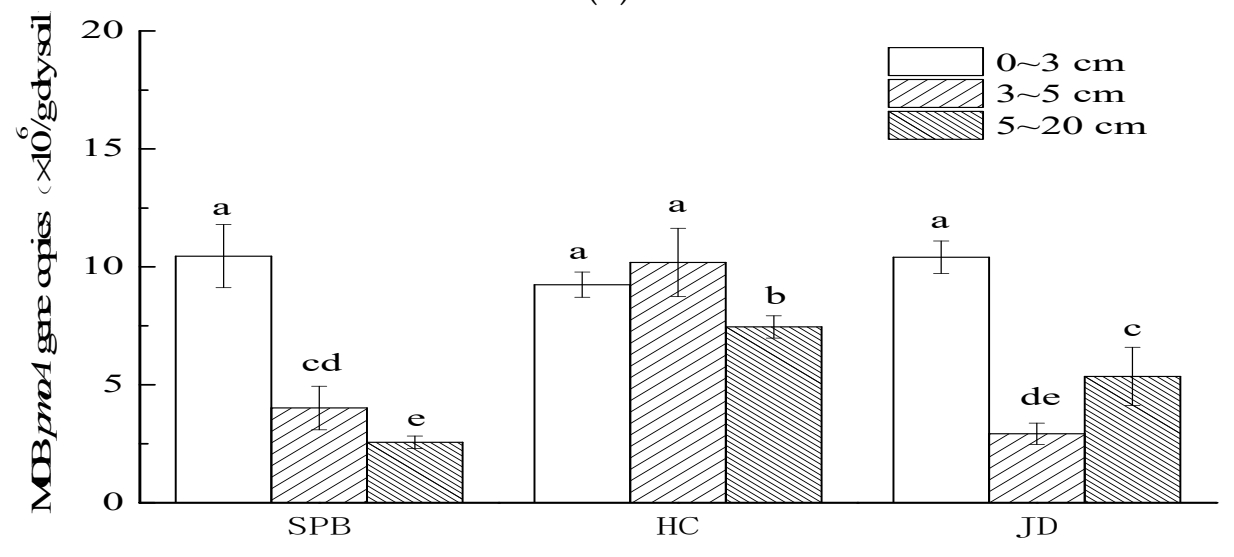

(c)

Figure 3. (a) AOA, (b) AOB, and (c) MOB community abundance in different soil layers in all the flooded paddy fields. Values are the averages of triplicate samples. Vertical bars indicate standard deviations. Different letters above the columns indicate significant differences $p<0.05$. 
Table 4. Relative abundances of functional gene copy numbers for different soil layers in flooded paddy fields.

\begin{tabular}{lccccccccc}
\hline & \multicolumn{3}{c}{ SPB } & \multicolumn{3}{c}{ HC } & \multicolumn{3}{c}{ JD } \\
\cline { 2 - 11 } & $\mathbf{0 - 3} \mathbf{~ c m}$ & $\mathbf{3 - 5} \mathbf{~ c m}$ & $\mathbf{5 - 2 0} \mathbf{~ c m}$ & $\mathbf{0 - 3} \mathbf{~ c m}$ & $\mathbf{3 - 5} \mathbf{~ c m}$ & $\mathbf{5 - 2 0} \mathbf{~ c m}$ & $\mathbf{0 - 3} \mathbf{~ c m}$ & $\mathbf{3 - 5} \mathbf{~ c m}$ & $\mathbf{5 - 2 0} \mathbf{~ c m}$ \\
\hline AOA/AOB & 20.7 & 7.04 & 28.6 & 57.2 & 12.6 & 68.4 & 43.5 & 11.6 & 76.9 \\
AOA/MOB & 7.72 & 13.1 & 42.6 & 17.2 & 5.25 & 10.1 & 7.14 & 12.5 & 20.5 \\
AOB/MOB & 0.373 & 1.87 & 1.49 & 0.301 & 0.419 & 0.147 & 0.164 & 1.07 & 0.647 \\
\hline
\end{tabular}

Notes: 0-3 cm: surface layer, $3-5 \mathrm{~cm}$ : subsurface layer, $5-20 \mathrm{~cm}$ : bottom layer.

\section{4. $A O A, A O B$, and $M O B$ Community Composition}

A total of 90 positive sequences were used for $\mathrm{AOA}, \mathrm{AOB} a m o A$ and $\mathrm{MOB} p m o A$ functional gene sequencing and the construction of a clone library (Figure 4). Phylogenetic analysis revealed that the AOA amoA in the surface layer in HC belonged to Group 1.1b, while $97 \%$ of AOA amoA in the subsurface layer belonged to the subordinates Group $1.1 \mathrm{~b}$ and $3 \%$ to Group 1.1 a associated. Sixty-four percent of AOA amoA in the bottom layer belonged to the subordinates Group $1.1 \mathrm{~b}$ and $36 \%$ to Group 1.1 a associated (Figure 4a). In addition, the phylogenetic analysis revealed that $92 \%$ of AOA amoA in the surface layer of SPB belonged to Group 1.1b, while 8\% belonged to Group 1.1a. Fifty-six percent of AOA $a m o A$ in the subsurface layer of SPB belonged to subordinates Group $1.1 b$ and $44 \%$ to Group $1.1 a$ associated; while in the bottom layer, $12 \%$ of the AOA amoA belonged to Group $1.1 b$, and $88 \%$ of the subordinates belonged to Group 1.1a associated (Figure 4b).

At the JD site, $84 \%$ of AOA amoA belonged to Group $1.1 \mathrm{~b}$ and $16 \%$ to Group $1.1 \mathrm{a}$, while $36 \%$ belonged to Group $1.1 b$ and $64 \%$ belonged to Group $1.1 a$ in the subsurface and the bottom layers (Figure 4c). Nitrosospira clusters were observed in the surface and bottom layers, accounting for $17 \%$ and $14 \%$, respectively. In addition, the community diversity of $\mathrm{AOA}$ exceeded that of $\mathrm{AOB}$ considerably, and AOB amoA was affiliated only with Nitrosomonas in the HC and SPB sites (Figure 5).

The phylogenetic analysis of MOB $p m o A$ assigned $69 \%$ of the sequences to Type Ia and the residual $31 \%$ of the sequences to type II MOB in the HC surface layer. In the HC subsurface layer, MOB pmoA consisted of subordinate Type Ia (18\%), Type Ib (37\%) and Type II ( $45 \%)$. In the HC bottom layer, $24 \%$ of the sequences belonged to Type Ib and 76\% belonged to Type II. In the surface layer at the SPB site, only $11 \%$ of the sequences were assigned to type II methanotrophs while the rest belonged to Type Ia (30\%) and Type $\mathrm{Ib}(59 \%)$. In the SPB subsurface layer, $44 \%$ of the sequences were associated with Type $\mathrm{Ib}$, and $56 \%$ were associated with Type I methanotrophs. Only $8 \%$ of MOB pmoA sequences were classified into Type Ia methanotrophs and the rest were associated with Type II. In the surface layer of the JD site, $17 \%$ of the sequences were assigned to Type Ia and the rest of the sequences were type $\mathrm{Ib}$ MOBs. The subsurface MOB pmoA belonged to Type Ib bacteria (38\%) and Type II bacteria (62\%). For the bottom layer soil at the JD site, the sequences belonged to Type Ia (25\%), Type Ib (21\%) and Type II (54\%) (Figure 6). 


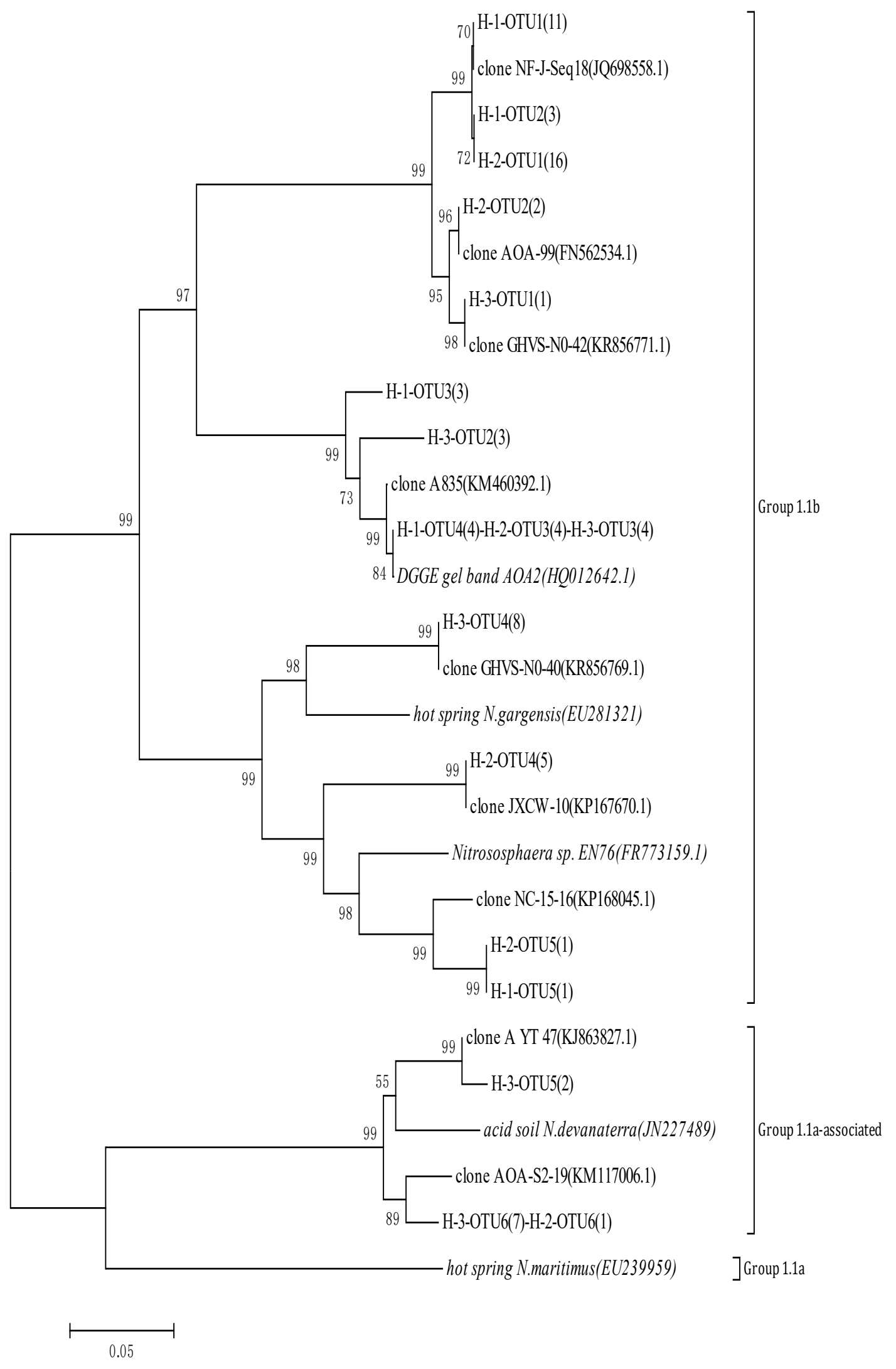

(a)

Figure 4. Cont. 


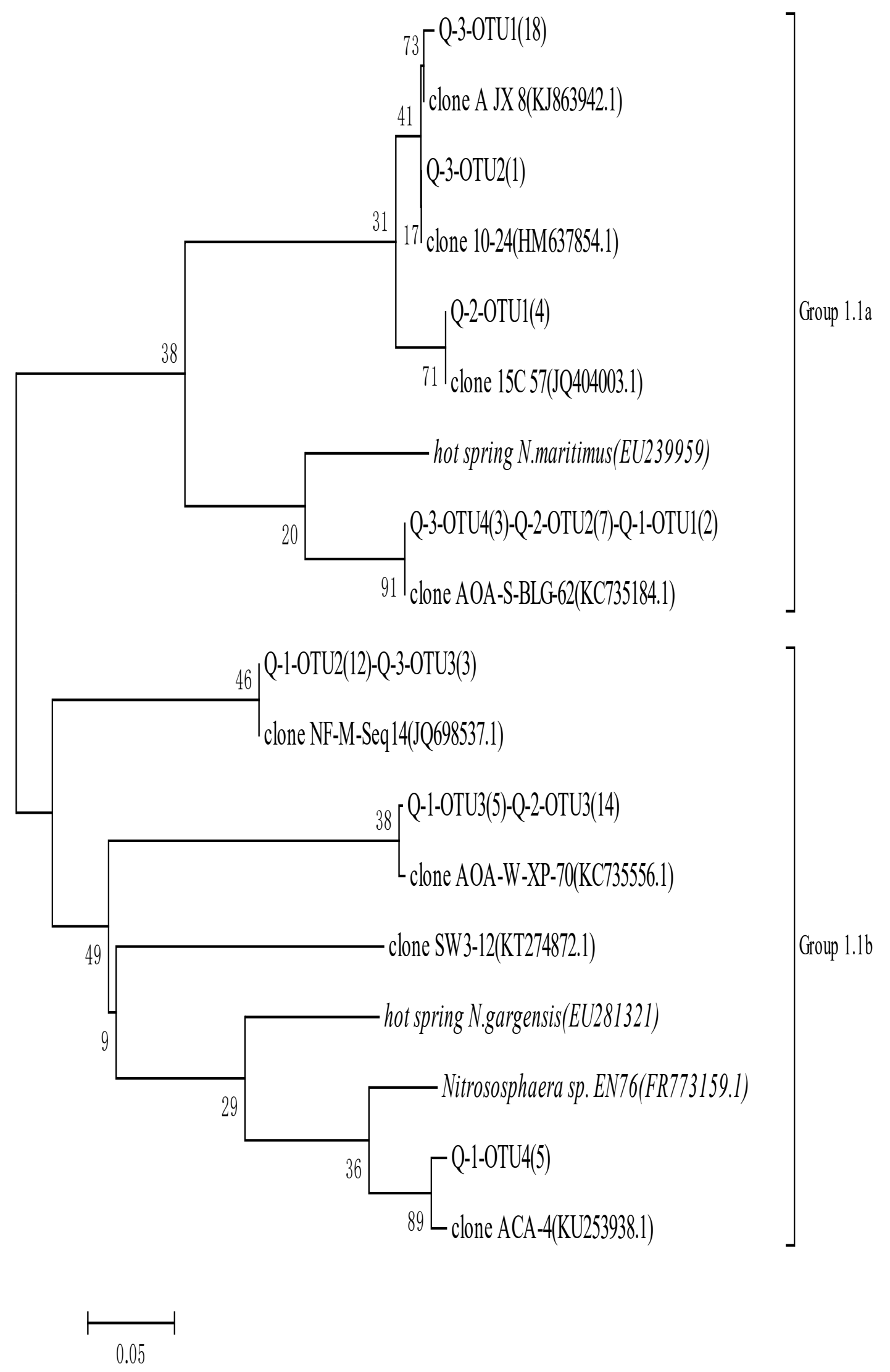

(b)

Figure 4. Cont. 


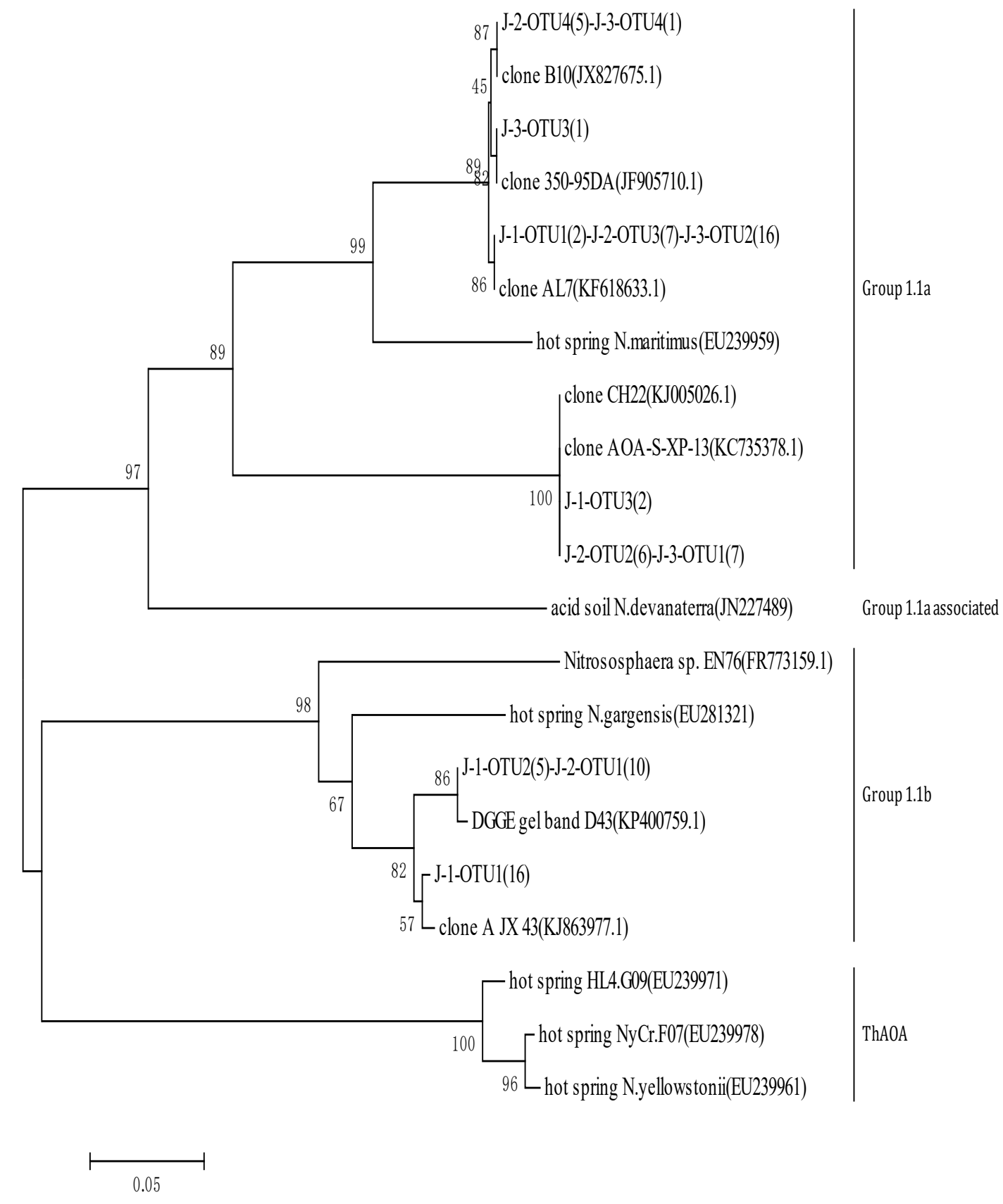

(c)

Figure 4. Phylogenetic tree of AOA amoA in different soil layers in (a) HC, (b) SPB, and (c) JD soil samples. The number in brackets after the gene or clone name represents the sequence number of the OTU. The scale represents the genetic distance, and the number represents five differences in every 100 bases.H-1 represents a $0-3 \mathrm{~cm}$ soil layer, $\mathrm{H}-2$ represents a $3-5 \mathrm{~cm}$ soil layer and $\mathrm{H}-3$ represents a $5-20$ $\mathrm{cm}$ soil layer in Figure 4a;Q-1 represents a 0-3 cm soil layer, Q-2 represents a $3-5 \mathrm{~cm}$ soil layer and Q-3 represents a 5-20 $\mathrm{cm}$ soil layer in Figure $4 \mathrm{~b}$;J -1 represents a $0-3 \mathrm{~cm}$ soil layer, J-2 represents a 3-5 $\mathrm{cm}$ soil layer, and J-3 represents a 5-20 cm soil layer in Figure 4c.The scale indicates the number of nucleotide substitutions per site. 


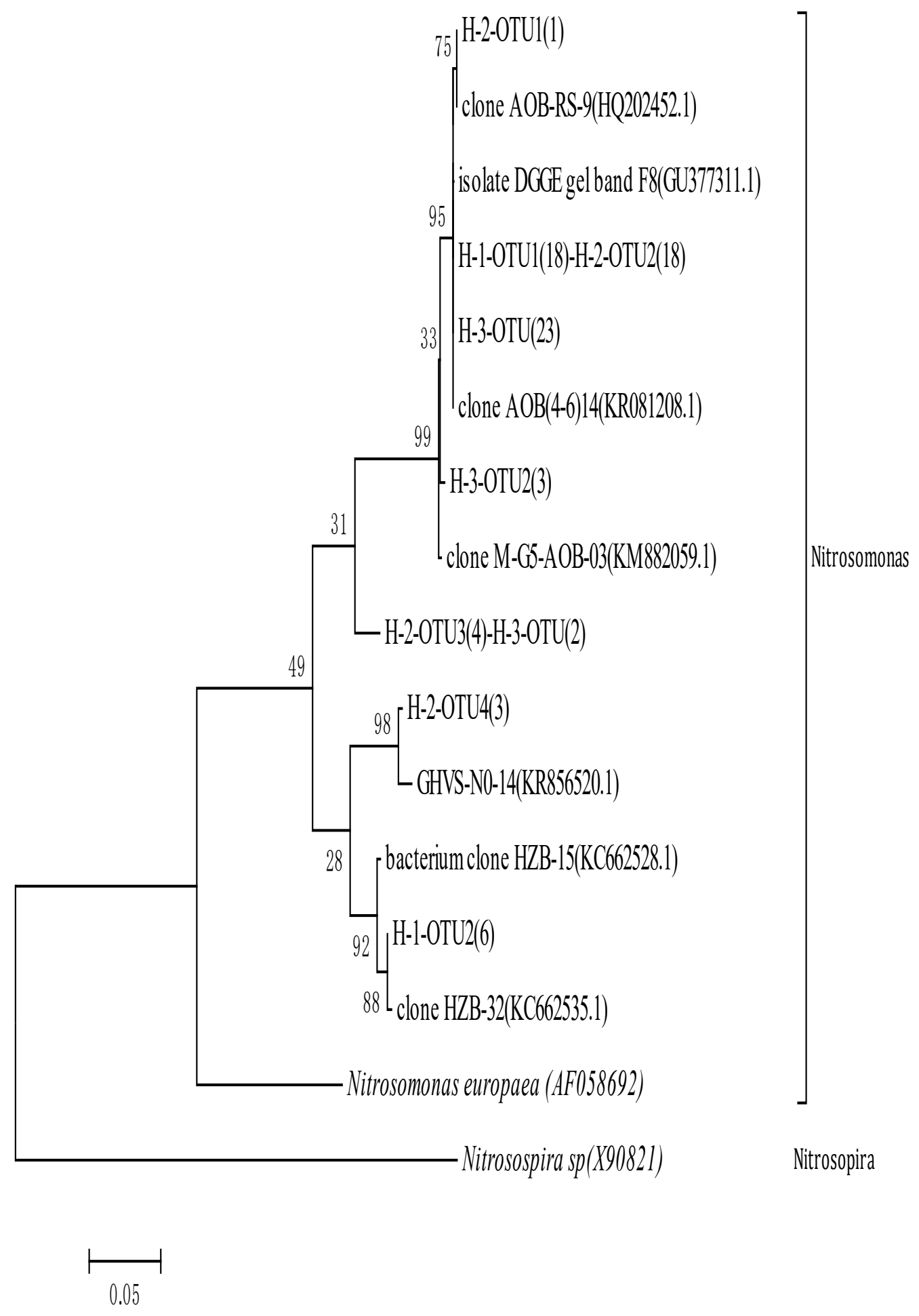

(a)

Figure 5. Cont. 


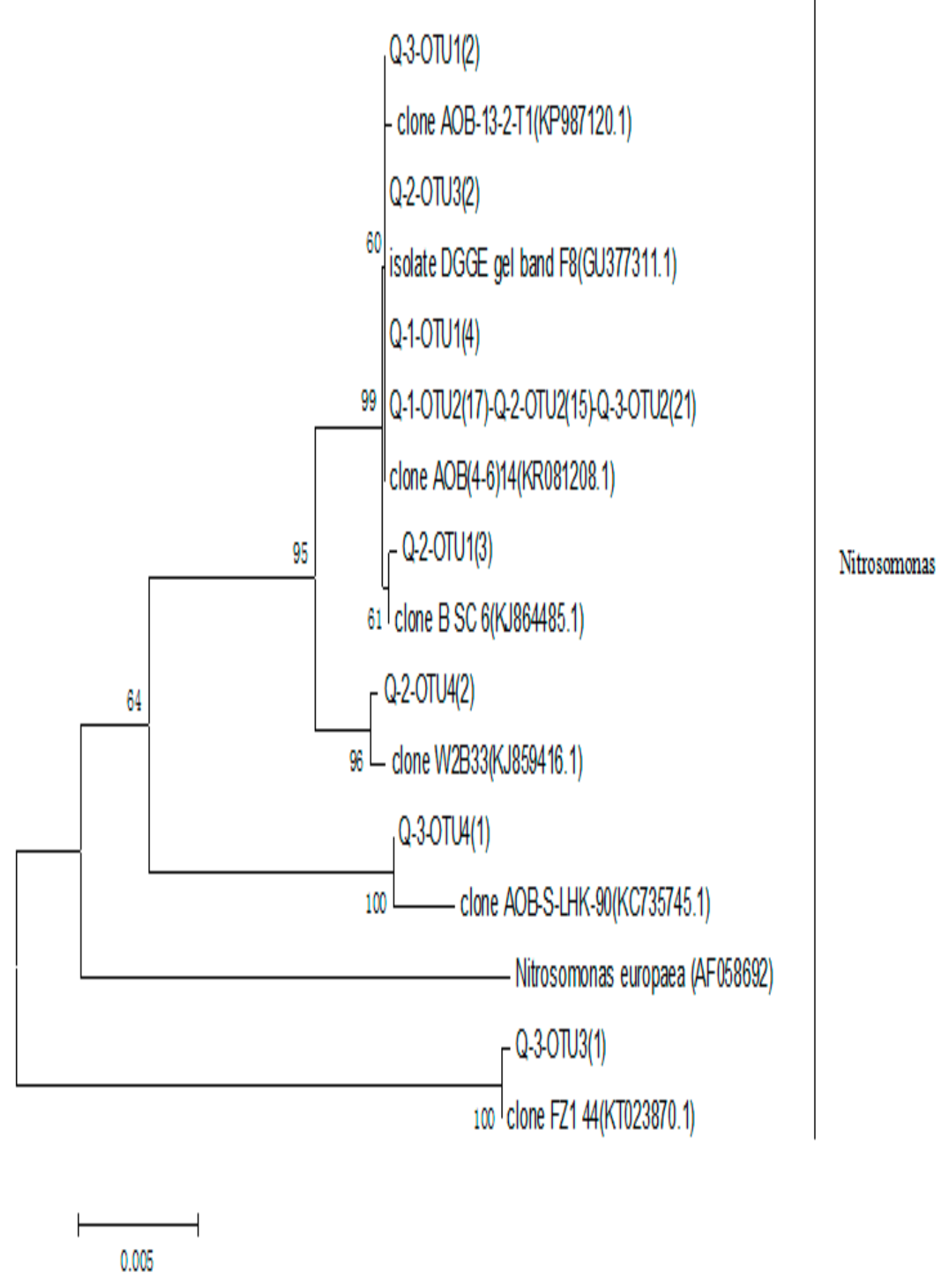

(b)

Figure 5. Cont. 


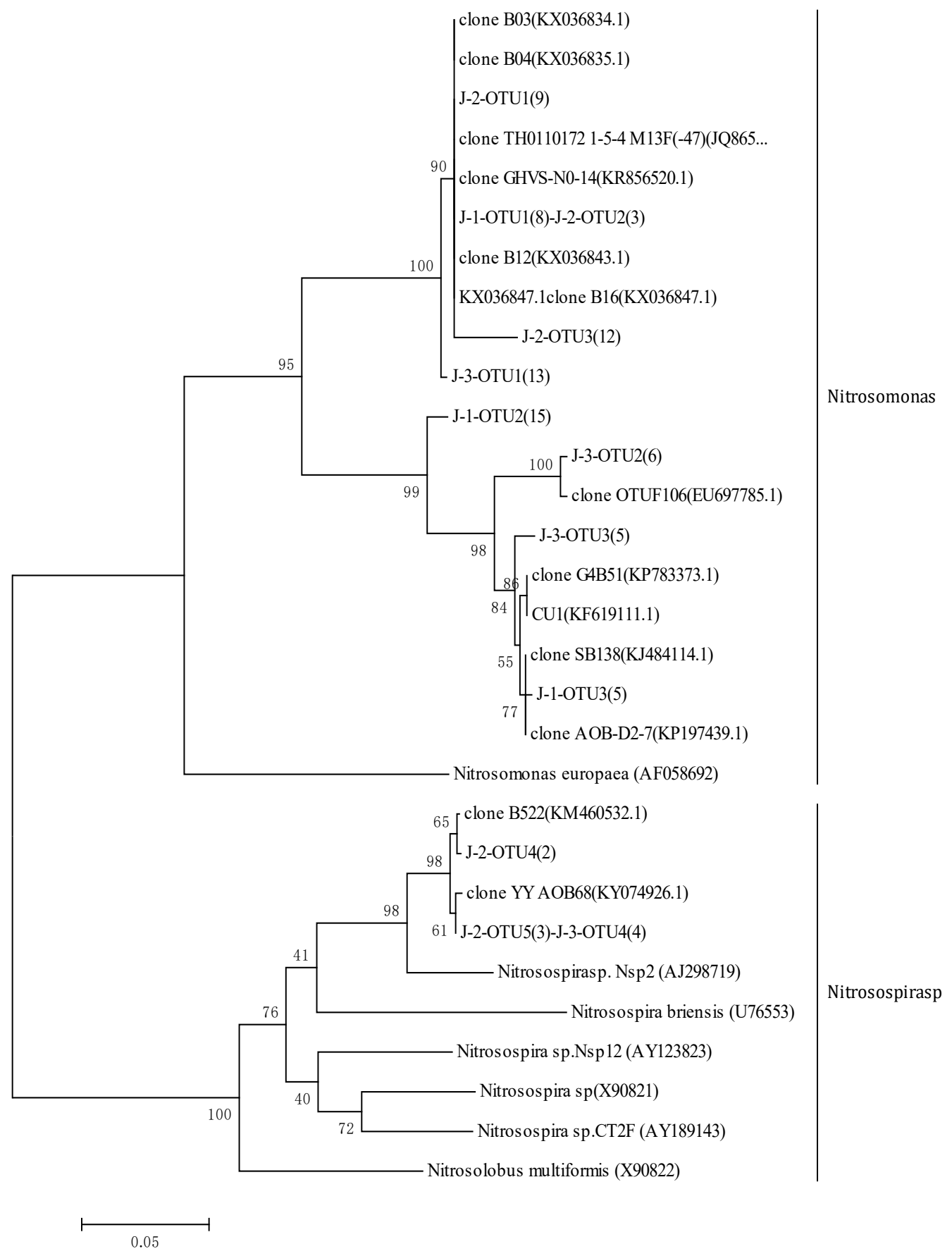

(c)

Figure 5. Phylogenetic tree of AOB amoA in different soil layers in (a) HC, (b) SPB and (c) JD soil samples. The number in brackets after the gene or clone name represents the sequence number of the OTU. The scale represents the genetic distance, and the number represents five differences in every 100 bases. $\mathrm{H}-1$ represents a $0-3 \mathrm{~cm}$ soil layer, $\mathrm{H}-2$ represents a $3-5 \mathrm{~cm}$ soil layer and $\mathrm{H}-3$ represents a $5-20$ $\mathrm{cm}$ soil layer in Figure 5a; Q-1 represents a 0-3 cm soil layer, Q-2 represents a $3-5 \mathrm{~cm}$ soil layer, and Q-3 represents a 5-20 cm soil layer in Figure 5b;J-1 represents a $0-3 \mathrm{~cm}$ soil layer, J-2 represents a 3-5 $\mathrm{cm}$ soil layer, and J-3 represents a $5-20 \mathrm{~cm}$ soil layer in Figure $5 \mathrm{c}$. The scale indicates the number of nucleotide substitutions per site. 


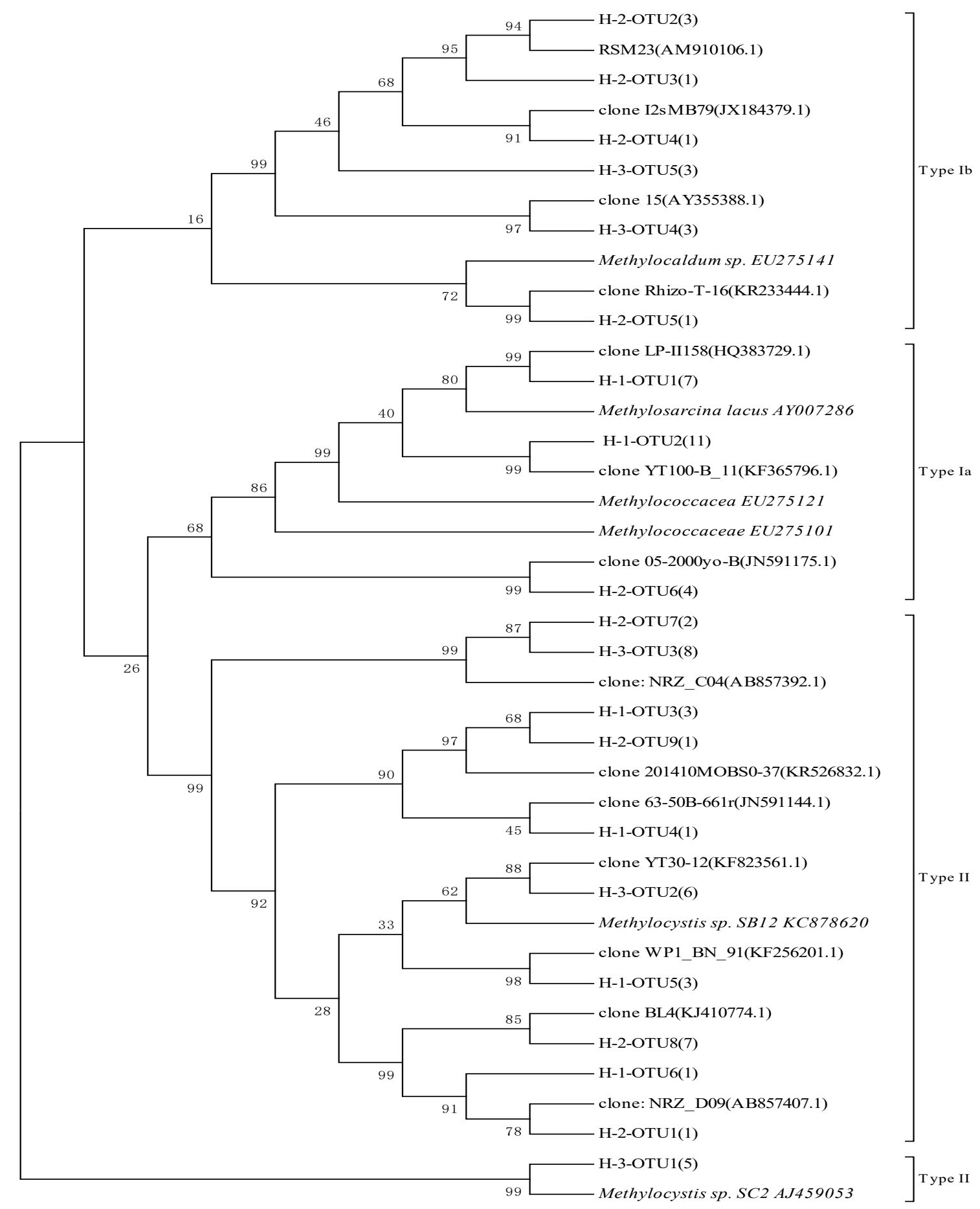

(a)

Figure 6. Cont. 


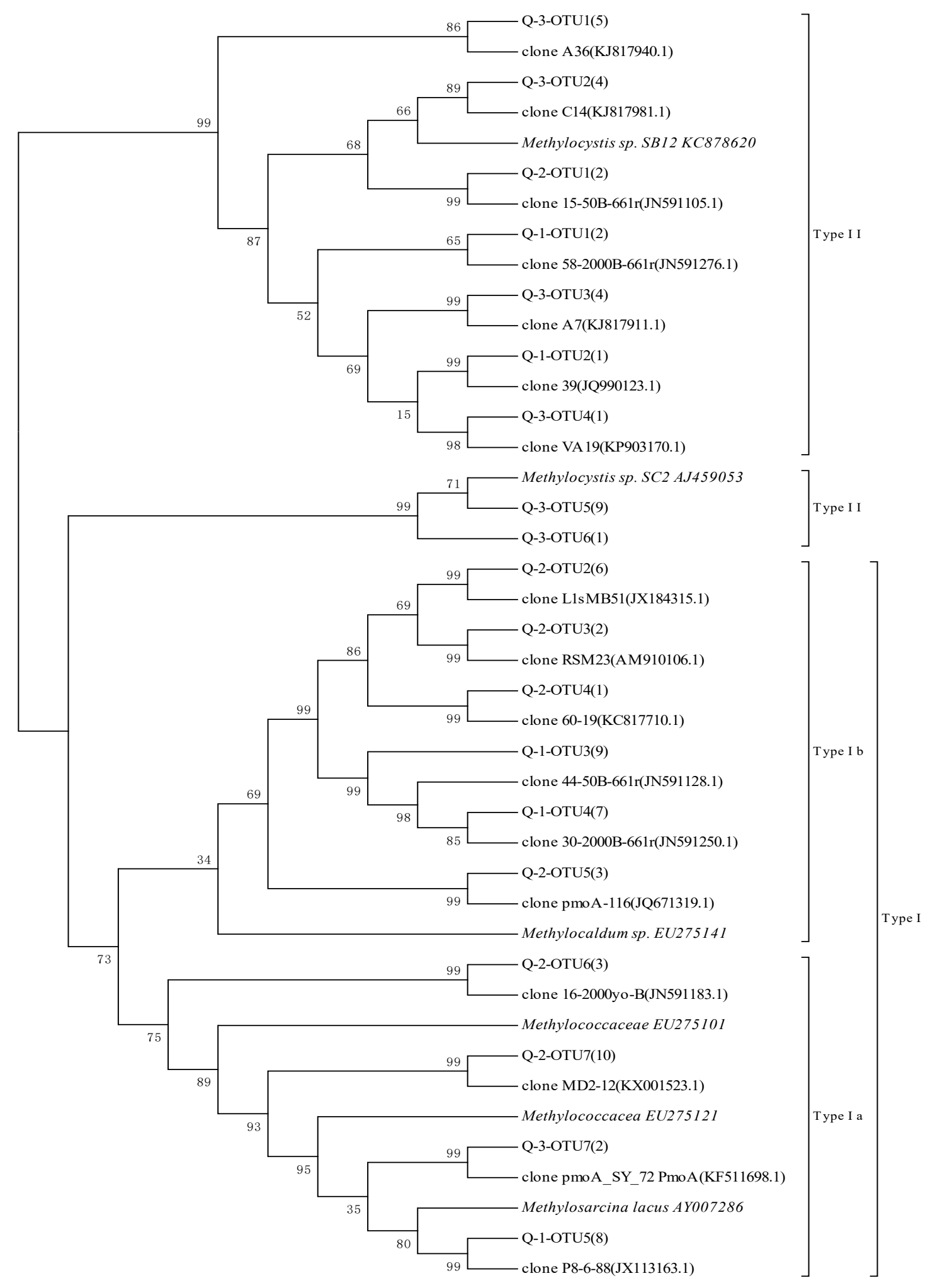

(b)

Figure 6. Cont. 


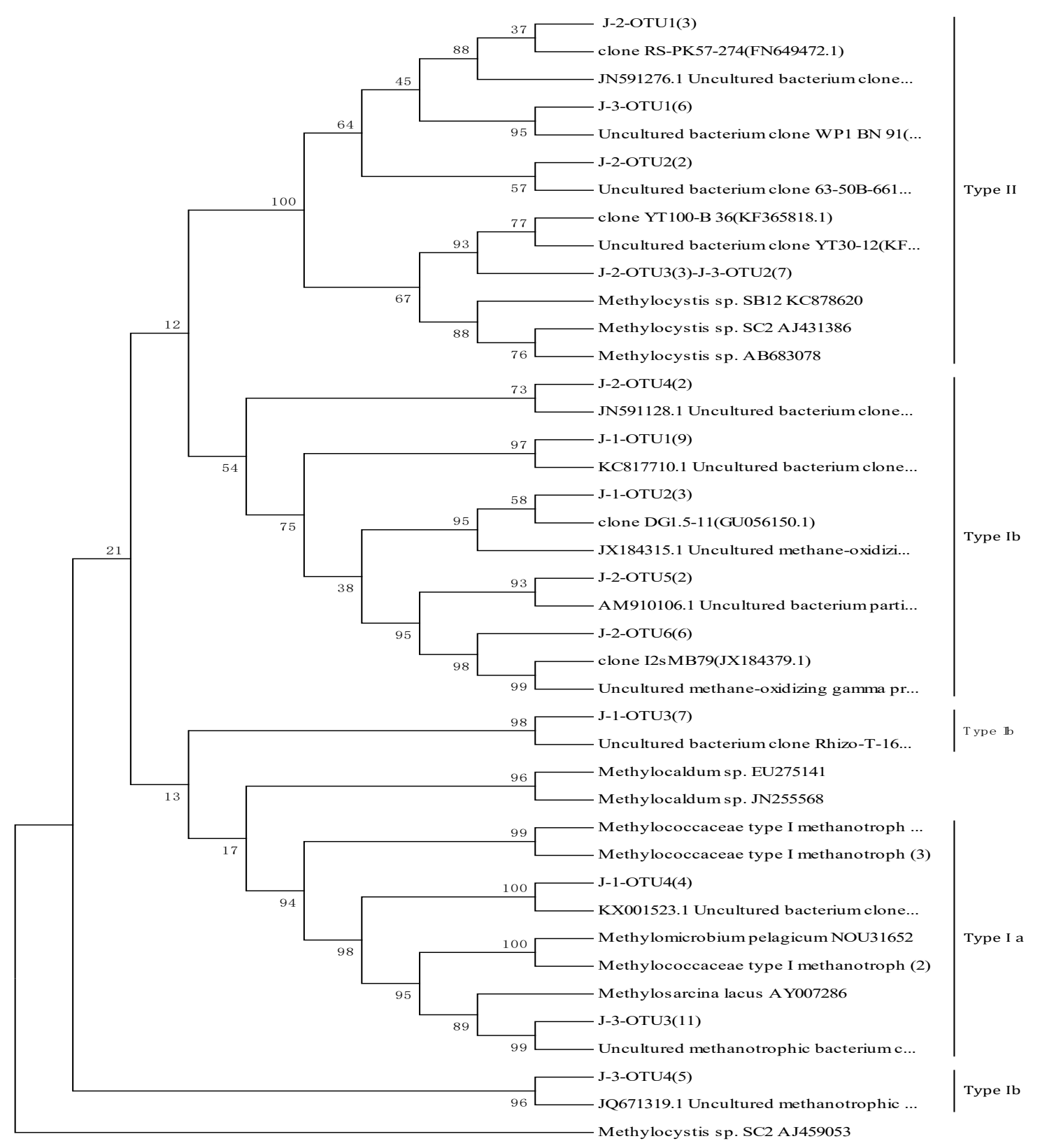

(c)

Figure 6. Phylogenetic tree of MOB pmoA in different soil layers in (a) HC, (b) SPB and (c) JD soil samples. The number in brackets after the gene or clone name represents the sequence number of the OTU. The scale represents the genetic distance, and the number represents five differences in every 100 bases. $\mathrm{H}-1$ represents a $0-3 \mathrm{~cm}$ soil layer, $\mathrm{H}-2$ represents a $3-5 \mathrm{~cm}$ soil layer and $\mathrm{H}-3$ represents a 5-20 cm soil layer in Figure 6a; Q-1 represents a 0-3 cm soil layer, Q-2 represents a 3-5 cm soil layer and Q-3 represents a $5-20 \mathrm{~cm}$ soil layer in Figure $6 \mathrm{~b}$; J-1 represents a $0-3 \mathrm{~cm}$ soil layer, J-2 represents a $3-5 \mathrm{~cm}$ soil layer and J-3 represents a $5-20 \mathrm{~cm}$ soil layer in Figure $6 \mathrm{c}$. The scale indicates the number of nucleotide substitutions per site. Numbers in parentheses against each abbreviation indicate the number of sequences recovered from each sample. 


\section{Discussion}

\subsection{Spatial Occurrence and Abundance of $A O A, A O B$ and $M O B$ among the FPFs}

The present study explored the occurrence and niche distribution of $\mathrm{AOA}, \mathrm{AOB}$ and $\mathrm{MOB}$ among three FPFs. Although some studies have suggested that the oxidation of $\mathrm{NH}_{3}$ is mainly attributed to AOA [31,32], the presence of both AOA and AOB in all the three FPFs in the present study indicated that the two groups could jointly play a role in the transformation of $\mathrm{NH}_{3}$ to $\mathrm{NO}_{3}{ }^{-}$. Consistent with the findings of previous studies across different ecosystems [16,33], we observed that AOA abundance has a more considerable role than $\mathrm{AOB}$ and $\mathrm{MOB}$ across the three FPFs, with the highest amoA observed in the bottom soil layers, particularly in the SPB and JD sites.

Although the results of previous studies have suggested that AOA numerically outnumber $\mathrm{AOB}$ in acidic soil, in the present study we observed that despite the soil $\mathrm{pH}$ values across the FPFs moving away from being acidic to alkaline (Table 1), the AOA abundance was still significantly higher than AOB abundance in all FPFs, and were consistent with the higher potential nitrification rates (PNRs), particularly in the SPB and JD sites. The results indicated a reduced affinity of soil $\mathrm{pH}$ and AOA for $\mathrm{NH}_{3}$, which enabled them to utilize low concentrations of $\mathrm{NH}_{3}$ in the acidic soils and thus influenced their abundance in the present study. However, the higher AOA observed in the present study could be attributed to their capacity to adapt to low $\mathrm{O}_{2}$ concentration environments, which is a common phenomenon in paddy fields [34], or the high organic matter concentrations that create $\mathrm{NH}_{3}$ assimilation pathways in all the three sites (Table 1 in reference [35]). In addition, although the $\mathrm{AOA} / \mathrm{AOB}$ ratio was higher than 10 in all the three sites, the $\mathrm{AOB} / \mathrm{MOB}$ ratio was much lower than ten, indicating that the $\mathrm{AOA}$ amo $A$ functional gene copy numbers in the three sites were significantly higher than the $\mathrm{AOB}$ amo $A$ and $\mathrm{MOB}$ pmoA functional gene copy numbers, by at least one order of magnitude. Since potential nitrifying activity is linked strongly to soil $\mathrm{NO}_{2}{ }^{-}$content, the higher PNRs in the $3-5 \mathrm{~cm}$ soil layer indicated that the risk of $\mathrm{NO}_{2}^{-}$leaching could be higher in the surface soil. Therefore, in all the studied flooded paddy fields, the surface soil requires more attention with regard to $\mathrm{NO}_{2}{ }^{-}$leaching.

Unlike AOA and AOB, approximately $50 \%$ to $90 \%$ of the $\mathrm{CH}_{4}$ in the soil surface and the rhizosphere is oxidized by MOB prior to being emitted into the atmosphere, thus there is a need to pay further attention to their occurrence and distribution in FPFs [6]. Similar to AOA and AOB, MOB occurred in all the studied FPFs and there was no significant difference in their abundance among the sites. However, the potential $\mathrm{CH}_{4}$ oxidation rates across the FPFs indicated that SPB paddy fields had the capacity to increase $\mathrm{CH}_{4}$ oxidation capacity considerably compared to the other FPFs (Figure 2). MOB abundance across the FPFs was low compared to AOA and AOB abundance, which suggests that although MOB might contribute significantly to the nitrification process in all the three FPFs, their specific nitrification rates could be much lower than the AOA and AOB nitrification rates [5].

\subsection{Community Structure of $A O A, A O B$, and $M O B$ at Different Soil Depth among the FPFs}

The results of the phylogenetic analysis in the present study revealed that the members of three archaea genera, including Nitrososphaera, Nitrosopumilus, and Nitrosotalea were enriched in the three FPFs. Members of bacterial genus Nitrosomonas were the most dominant $\mathrm{NH}_{3}$ oxidizers in all the soils. In addition, genus Nitrososphaera was among the most abundant $\mathrm{NH}_{3}$ oxidizers in the $\mathrm{HC}$ and the SPB surface soil. Members of genus Nitrosotalea were highly enriched in the JD subsurface and bottom soil layers, while members of Nitrosopumilus were only dominant in the JD subsurface and bottom soil layers, and Nitrososphaera were still dominant in the surface layer. The results indicated that different $\mathrm{NH}_{3}$ oxidizers occupied different environmental niches in the FPFs. Several factors, including substrate concentration, $\mathrm{pH}$, temperature and $\mathrm{O}_{2}$ have been reported to influence the structural composition of $\mathrm{NH}_{3}$ oxidizers in different ecosystems [36,37]. However, the distinction in the community structure across the FPFs in the present study could not be attributed solely to the environmental drivers because there were no significant differences in either temperature or $\mathrm{pH}$ among the FPFs. 
In the present study, MOB pmoA distribution in the FPFs varied considerably; however, community distribution increased with an increase in the soil layer depth. Type I MOB were enriched in the surface and subsurface layers, although Type II MOB were enriched in the bottom layer. The results indicated that type I MOB abundance was higher than type II MOB, which was consistent with the findings of Steenbergh et al. (2010) [38], who proposed different life strategies for type I and type II methanotroph. It has been reported that Type I MOB preferentially grow at high $\mathrm{O}_{2}$ and low $\mathrm{CH}_{4}$ concentration environments, while Type II MOB preferentially grow at low $\mathrm{O}_{2}$ and high $\mathrm{CH}_{4}$ concentration environments [39]. Therefore, Type I and II MOB occupy different niches [40]. The results also demonstrated the uniqueness of each soil environment and the effects of ecological factors on MOB at the species level. The MOB communities in the FPFs were relatively stable. The Type I MOB belong to the Methylococcaceae type I methanotroph genera (Type I a) and the genus Methylocaldum (Type I b), while Type II MOB are the genus Methylocystis. The results are consistent with the findings of a previous study that suggested that the major contributor to $\mathrm{CH}_{4}$ oxidation in the atmosphere is type II MOB, particularly Methylocystis sp [41]. Plant cultivation, moisture content and temperature also influence MOB diversity [42]. In addition, soil moisture could influence soil $\mathrm{CH}_{4}$ absorption [43]. In the present study, the application of fertilizer in paddy fields enhanced $\mathrm{CH}_{4}$ oxidation. The inorganic

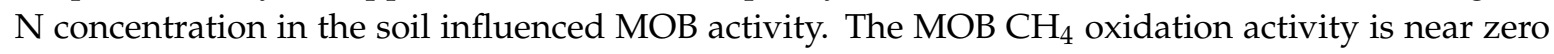
when $\mathrm{N}$ ions in the soil are exhausted, with three potential mechanisms: (1) $\mathrm{NH}_{4}{ }^{+}$- or $\mathrm{NO}_{2}{ }^{-}$-nitrogen increase the activity of $\mathrm{CH}_{4}$ oxidizing microorganisms; (2) $\mathrm{N}$ participates in the synthesis of enzymes involved in $\mathrm{CH}_{4}$ oxidation; and (3) an increase in nitrification bacteria diversity and activity could enhance $\mathrm{CH}_{4}$ oxidation [44,45]. Nevertheless, the specific mechanism of action requires further study.

\section{Conclusions}

This study highlighted that AOA abundance was higher than AOB and MOB abundance in all the FPFs, which was consistent with the potential nitrification rates (PNRs), particularly in the SPB and JD sites. Three AOA genera (Nitrososphaera, Nitrosopumilus, Nitrosotalea) were observed in all the FPFs, and Nitrososphaera were dominant in the surface layers. In addition, Nitrososphaera were among the most abundant $\mathrm{NH}_{3}$ oxidizers in the $\mathrm{HC}$ and in the SPB surface soil, while members of genus Nitrosotalea were considerably enriched in the JD subsurface and bottom layers. MOB community distribution increased with an increase in the depths of the soil layers, and Type I MOB were enriched in the surface and subsurface layers, while Type II MOB were enriched in the bottom layers. Overall, this study provides a basis for improving soil nitrogen use efficiency and mitigating soil greenhouse gas emissions in flooded paddy fields.

Author Contributions: Conceptualization, J.Z. and H.L.; Data curation, O.A.O. and J.L. (Jiabao Li); Formal analysis, J.Z., O.A.O., K.P., Y.M., J.L.(Jianjun Li), J.L.(Jiabao Li) and S.S.; Funding acquisition, H.L.; Methodology, K.P., S.S. and D.G.; Software, X.J., Y.M., J.L.(Jianjun Li) and D.G.; Supervision, H.L.; Writing - original draft, J.Z. and O.A.O.; Writing-review \& editing, O.A.O., K.P., X.J., Y.M. and H.L. All authors have read and agreed to the published version of the manuscript.

Acknowledgments: This study was financially supported by the National Natural Science Foundation of China (No.41301315), Fundamental Research Funds for the Central Universities (XDJK 2019B072), and the Natural Science Foundation of Chongqing municipality (Cstc2012JJA80024, cstc2019jcyj-msxmX0304).

Conflicts of Interest: Authors declare that they have no conflict of interest.

\section{References}

1. Song, H.; Che, Z.; Cao, W.; Huang, T.; Wang, J.; Dong, Z. Changing roles of ammonia-oxidizing bacteria and archaea in a continuously acidifying soil caused by over-fertilization with nitrogen. Environ. Sci. Pollut. Res. 2016, 23, 11964-11974. [CrossRef] [PubMed]

2. Leininger, S.; Urich, T.; Schloter, M.; Schwark, L.; Qi, J.; Nicol, G.W.; Prosser, J.I.; Schuster, S.C.; Schleper, C. Archaea predominate among ammonia-oxidizing prokaryotes in soils. Nat. 2006, 442, 806-809. [CrossRef] [PubMed] 
3. Zheng, Y.; Zhang, L.-M.; Zheng, Y.-M.; Di, H.; He, J.-Z. Abundance and community composition of methanotrophs in a Chinese paddy soil under long-term fertilization practices. J. Soils Sediments 2008, 8 , 406-414. [CrossRef]

4. Qiu, Q.; Noll, M.; Abraham, W.-R.; Lu, Y.; Conrad, R. Applying stable isotope probing of phospholipid fatty acids and rRNA in a Chinese rice field to study activity and composition of the methanotrophic bacterial communities in situ. ISME J. 2008, 2, 602-614. [CrossRef] [PubMed]

5. Yang, Y.; Shan, J.; Zhang, J.; Zhang, X.; Xie, S.; Liu, Y. Ammonia- and methane-oxidizing microorganisms in high-altitude wetland sediments and adjacent agricultural soils. Appl. Microbiol. Biotechnol. 2014, 98, 10197-10209. [CrossRef]

6. Bodelier, P.L.E.; Roslev, P.; Henckel, T.; Frenzel, P. Stimulation by ammonium-based fertilizers of methane oxidation in soil around rice roots. Nat. 2000, 403, 421-424. [CrossRef]

7. Faostat, F. Agricultural Organization of the United Nations. 2010. Available online: faostat.fao.org (accessed on 2 May 2019).

8. Stieglmeier, M.; Kling, A.; Alves, R.J.E.; Rittmann, S.K.M.R.; Melcher, M.; Leisch, N.; Schleper, C. Nitrososphaera viennensisgen. nov., sp. nov., anaerobic and mesophilic, ammonia-oxidizing archae from soil and a member of the archaeal phylum Thaumarchaeota. Int. J. Syst. Evol. Microbiol. 2014, 64, 2738-2752. [CrossRef]

9. Kampschreur, M.J.; Van Der Star, W.R.; Wielders, H.A.; Mulder, J.W.; Jetten, M.S.; Van Loosdrecht, M.C. Dynamics of nitric oxide and nitrous oxide emission during full-scale reject water treatment. Water Res. 2008, 42, 812-826. [CrossRef]

10. Blainey, P.C.; Mosier, A.C.; Potanina, A.; Francis, C.A.; Quake, S.R. Genome of a Low-Salinity Ammonia-Oxidizing Archaeon Determined by Single-Cell and Metagenomic Analysis. PLoS ONE 2011, 6, e16626. [CrossRef]

11. Tourna, M.; Freitag, T.E.; Nicol, G.W.; Prosser, J.I. Growth, activity and temperature responses of ammonia-oxidizing archaea and bacteria in soil microcosms. Environ. Microbiol. 2010, 10, 1357-1364. [CrossRef]

12. Zhang, M.-M.; Alves, R.J.; Zhang, D.-D.; Han, L.-L.; He, J.-Z.; Zhang, L.-M. Time-dependent shifts in populations and activity of bacterial and archaeal ammonia oxidizers in response to liming in acidic soils. Soil Boil. Biochem. 2017, 112, 77-89. [CrossRef]

13. Chen, Y.L.; Xu, Z.W.; Hu, H.W.; Hu, Y.J.; Hao, Z.P.; Jiang, Y.; Chen, B.D. Responses of ammonia-oxidizing bacteria and archaea to nitrogen fertilization and precipitation increment in a typical temperate steppe in Inner Mongolia [J]. Appl. Soil Ecol. 2013, 68, 36-45. [CrossRef]

14. Yao, H.Y.; Gao, Y.M.; Nicol, G.W.; Campbell, C.D.; Prosser, J.I.; Zhang, L.M.; Han, W.Y.; Singh, B.K. Links between ammonia oxidizer community structure, abundance, and nitrification potential in acidic soils. Appl. Environ. Microbiol. 2001, 77, 4618-4625. [CrossRef] [PubMed]

15. Jia, Z.; Conrad, R.; Jia, Z.J.; Conrad, R. Bacteria rather than Archaea dominate microbial ammonia oxidation in an agricultural soil. Environ Microbiol. 2009, 11, 1658-1671. [CrossRef]

16. Zhang, F.-Q.; Pan, W.; Gu, J.-D.; Xu, B.; Zhang, W.-H.; Zhu, B.-Z.; Wang, Y.-X.; Wang, Y.-F. Dominance of ammonia-oxidizing archaea community induced by land use change from Masson pine to eucalypt plantation in subtropical China. Appl. Microbiol. Biotechnol. 2016, 100, 6859-6869. [CrossRef]

17. Lehtovirta-Morley, L.E.; Stoecker, K.; Vilcinskas, A.; Prosser, J.I.; Nicol, G.W. Cultivation of an obligate acidophilic ammonia oxidizer from a nitrifying acid soil [J]. Proc. Natl. Acad. Sci. USA. 2011, 108, 15892-15897. [CrossRef]

18. Ying, J.-Y.; Zhang, L.-M.; He, J.-Z. Putative ammonia-oxidizing bacteria and archaea in an acidic red soil with different land utilization patterns. Environ. Microbiol. Rep. 2010, 2, 304-312. [CrossRef]

19. Zhang, J.; Liu, B.; Zhou, X.; Chu, J.; Li, Y.; Wang, M. Effects of emergent aquatic plants on abundance and community structure of ammonia-oxidising microorganisms. Ecol. Eng. 2015, 81, 504-513. [CrossRef]

20. Shen, J.-P.; Zhang, L.-M.; Zhu, Y.-G.; Zhang, J.-B.; He, J.-Z. Abundance and composition of ammonia-oxidizing bacteria and ammonia-oxidizing archaea communities of an alkaline sandy loam. Environ. Microbiol. 2008, 10, 1601-1611. [CrossRef]

21. Shen, X.Y.; Zhang, L.M.; Shen, J.P.; Li, L.H.; Yuan, C.L.; He, J.Z. Nitrogen loading levels affect abundance and com-position of soil ammonia oxidizing prokaryotes in semiarid temper-ate grassland. J. Soil Sediment. 2011, 11, 1243-1252. [CrossRef] 
22. Walkey, A.; Black, I.A. An examination of the Different method for determining soil organic matter, and a proposed modification of the chromic acid titration method. Soil Sci. 1934, 34, 29-38. [CrossRef]

23. U.S. EPA Method Determination of Total Kjeldahl Nitrogen by Semi-Automated Colorimetry; EPA: Cincinnati, Ohio, USA, August 1993; 351, p. 2.

24. Jiang, X.; Hou, X.; Zhou, X.; Xin, X.; Wright, A.; Jia, Z. pH regulates key players of nitrification in paddy soils. Soil Boil. Biochem. 2015, 81, 9-16. [CrossRef]

25. Lü, Z.-M.; Min, H.; Chen, Z.-Y.; Lü, Q. [Contribution of anaerobic oxidation of methane to whole methane oxidation]. Huan jing ke xue= Huanjing kexue 2005, 26, 13-17. [PubMed]

26. Rotthauwe, J.H.; Witzel, K.P.; Liesack, W. The ammonia monooxygenase structural gene amoA as a functional marker: molecular fine-scale analysis of natural ammonia-oxidizing populations. Appl. Environ. Microbiol. 1997, 63, 4704-4712. [CrossRef] [PubMed]

27. Liebner, S.; Rublack, K.; Stuehrmann, T.; Wagner, D. Diversity of Aerobic Methanotrophic Bacteria in a Permafrost Active Layer Soil of the Lena Delta. Siberia. Microb Ecol. 2009, 57, 25-35. [CrossRef]

28. Beman, J.M.; Francis, C.A. Diversity of Ammonia-Oxidizing Archaea and Bacteria in the Sediments of a Hypernutrified Subtropical Estuary: Bahía del Tóbari, Mexico ${ }^{\nabla}$. Appl. Environ. Microbiol. 2006, 72, 7767-7777. [CrossRef]

29. Zhou, X.Q.; Wang, Y.F.; Huang, X.Z.; Tian, J.Q.; Hao, Y.B. Effect of grazing intensities on the activity and community structure of methane-oxidizing bacteria of grassland soil in inner mongolia. Nutr. Cycl. Agroecosys. 2008, 80, 145-152. [CrossRef]

30. Tamura, K.; Dudley, J.; Nei, M.; Kumar, S. MEGA4: Molecular Evolutionary Genetics Analysis (MEGA) Software Version 4.0. Mol. Boil. Evol. 2007, 24, 1596-1599. [CrossRef]

31. Isobe, K.; Koba, K.; Suwa, Y.; Ikutani, J.; Fang, Y.; Yoh, M.; Mo, J.; Otsuka, S.; Senoo, K. High abundance of ammonia-oxidizing archaea in acidified subtropical forest soils in southern China after long-term $\mathrm{N}$ deposition. FEMS Microbiol. Ecol. 2012, 80, 193-203. [CrossRef]

32. Zhang, L.M.; Hu, H.W.; Shen, J.P.; He, J.Z. Ammonia-oxidizing archaea have more important role than ammonia-oxidizing bacteria in ammonia oxidation of strongly acidic soils. Isme. J. 2012, 6, 1032-1045. [CrossRef]

33. Strauss, S.; Reardon, C.; Mazzola, M. The response of ammonia-oxidizer activity and community structure to fertilizer amendment of orchard soils. Soil Boil. Biochem. 2014, 68, 410-418. [CrossRef]

34. Bannert, A.; Mueller-Niggemann, C.; Kleineidam, K.; Wissing, L.; Cao, Z.-H.; Schwark, L.; Schloter, M. Comparison of lipid biomarker and gene abundance characterizing the archaeal ammonia-oxidizing community in flooded soils. Boil. Fertil. Soils 2011, 47, 839-843. [CrossRef]

35. Liu, Y.; Zhou, Z.; Pan, J.; Baker, B.J.; Gu, J.-D.; Li, M. Comparative genomic inference suggests mixotrophic lifestyle for Thorarchaeota. ISME J. 2018, 12, 1021-1031. [CrossRef] [PubMed]

36. Kemmitt, S.J.; Wright, D.; Goulding, K.W.; Jones, D.L. pH regulation of carbon and nitrogen dynamics in two agricultural soils. Soil Boil. Biochem. 2006, 38, 898-911. [CrossRef]

37. Liu, Z.; Xie, H.; Hu, Z.; Zhang, J.; Sun, H.; Lan, W. Role of Ammonia-Oxidizing Archaea in Ammonia Removal of Wetland Under Low-Temperature Condition. Water, Air, Soil Pollut. 2017, 228, 356-365. [CrossRef]

38. Steenbergh, A.K.; Meima, M.M.; Kamst, M.; Bodelier, P.L. Biphasic kinetics of â€fa methanotrophic community is a combination of growth and increased activity per cell. FEMS Microbiol. Ecol. 2010, 71, 12-22. [CrossRef]

39. Amaral, J.A.; Archambault, C.; Richards, S.R.; Knowles, R. Denitrification associated with groups i and ii methanotrophs in a gradient enrichment system. Fems. Microbiol. Ecology 2010, 18, 289-298. [CrossRef]

40. Abell, G.C.; Stralis-Pavese, N.; Sessitsch, A.; Bodrossy, L. Grazing affects methanotroph activity and diversity in an alpine meadow soil. Environ. Microbiol. Rep. 2010, 1, 457-465. [CrossRef]

41. Auman, A.J.; Stolyar, S.; Costello, A.M.; Lidstrom, M.E. Molecular Characterization of Methanotrophic Isolates from Freshwater Lake Sediment. Appl. Environ. Microbiol. 2000, 66, 5259-5266. [CrossRef]

42. Einola, J.-K.M.; Kettunen, R.H.; Rintala, J.A. Responses of methane oxidation to temperature and water content in cover soil of a boreal landfill. Soil Boil. Biochem. 2007, 39, 1156-1164. [CrossRef]

43. Stiehl-Braun, P.A.; Powlson, D.S.; Poulton, P.R.; Niklaus, P.A. Effects of N fertilizers and liming on the micro-scale distribution of soil methane assimilation in the long-term Park Grass experiment at Rothamsted. Soil Boil. Biochem. 2011, 43, 1034-1041. [CrossRef] 
44. Eller, G.; Frenzel, P. Changes in Activity and Community Structure of Methane-Oxidizing Bacteria over the Growth Period of Rice. Appl. Environ. Microbiol. 2001, 67, 2395-2403. [CrossRef] [PubMed]

45. Krüger, M.; Frenzel, P. Effects of N-fertilisation on $\mathrm{CH} 4$ oxidation and production, and consequences for $\mathrm{CH} 4$ emissions from microcosms and rice fields. Glob. Chang. Biol. 2010, 9, 773-784. [CrossRef]

(C) 2020 by the authors. Licensee MDPI, Basel, Switzerland. This article is an open access article distributed under the terms and conditions of the Creative Commons Attribution (CC BY) license (http://creativecommons.org/licenses/by/4.0/). 